\title{
Evidence for mega-landslides as drivers of island colonisation
}

\begin{tabular}{|r|l|}
\hline Journal: & Journal of Biogeography \\
\hline Manuscript ID & JBI-16-0566.R1 \\
\hline Manuscript Type: & Original Article \\
\hline Date Submitted by the Author: & n/a \\
\hline Complete List of Authors: & $\begin{array}{l}\text { Garcia Olivares, Víctor; Instituto de Productos Naturales y Agrobiologia, } \\
\text { Island Ecology and Evolution Research Group } \\
\text { López, Heriberto; Island Ecology and Evolution Research Group, IPNA-CSIC } \\
\text { Patiño, Jairo; Instituto de Productos Naturales y Agrobiologia, Island } \\
\text { Ecology and Evolution Research Group } \\
\text { Alvarez, Nadir; University of Lausanne, Department of Ecology and } \\
\text { Evolution, Biophore } \\
\text { Machado, Antonio; no institutional affiliation, NA } \\
\text { Carrecedo, Juan Carlos; Universidad de Las Palmas de Gran Canaria, } \\
\text { Departamento de Física (GEOVOL) } \\
\text { Soler, Vicente; Instituto de Productos Naturales y Agrobiologia, } \\
\text { Volcanology Group } \\
\text { Emerson, Brent; University of East Anglia, School of Biological Sciences }\end{array}$ \\
\hline Key Words: & $\begin{array}{l}\text { biogeography, invertebrate, dispersal, phylogeography, equilibrium theory, } \\
\text { rafting }\end{array}$ \\
\hline & \\
\hline
\end{tabular}




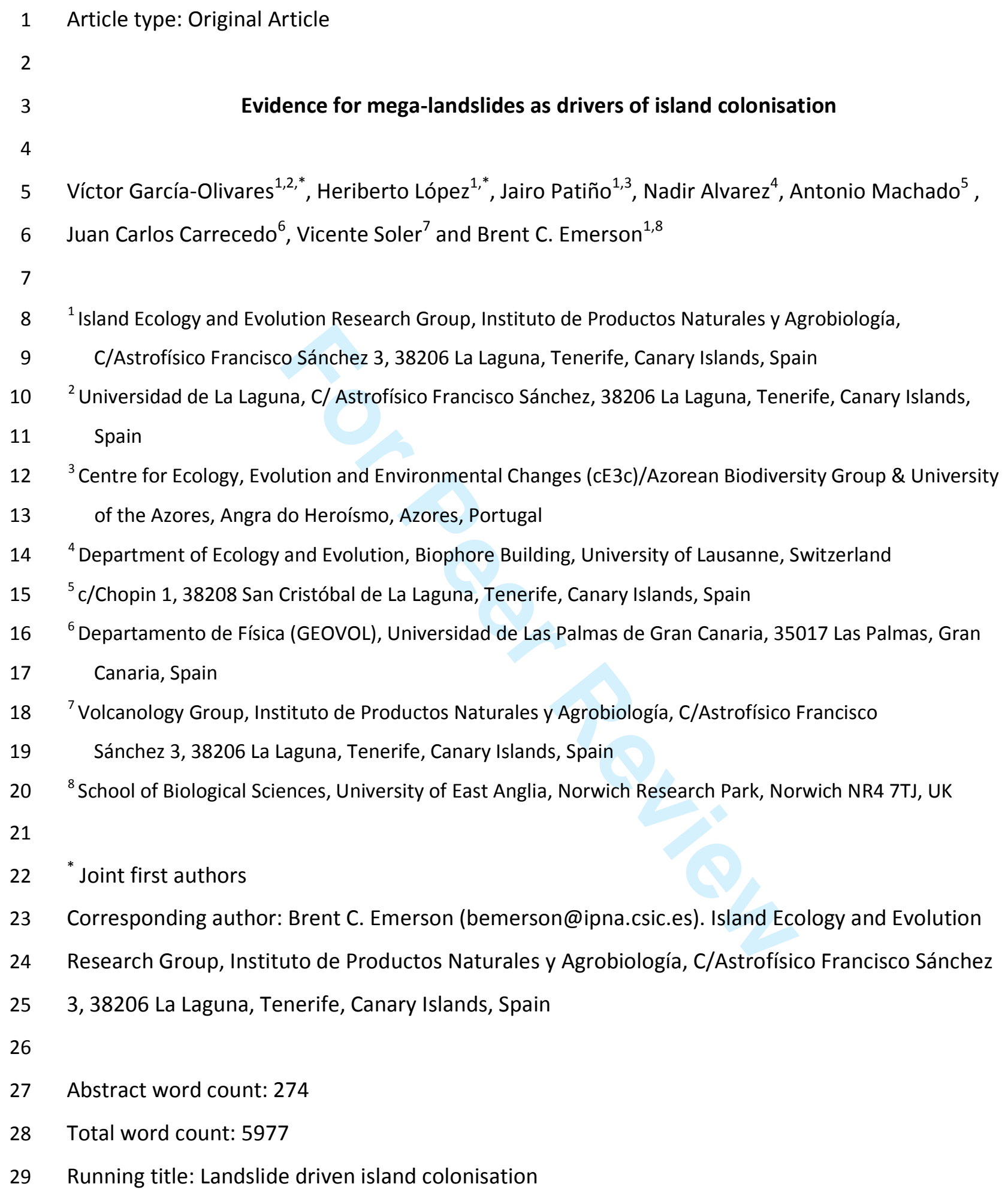


30

31

32

33

34

35

36

37

38

39

40

41

42

43

44

45

46

47

48

49

50

51

52

53

54

55

56

57

Abstract

Aim: How non-dispersive taxa colonise islands is generalised as being by wind, or rafting, with the implicit assumption that such events involve one (wind) or a few (rafting) individuals. However, because of the evolutionary timescale for colonisation events, the fit of individual species to a conceptual model of wind or rafting is difficult to assess. Here we describe an alternative testable geological model for inter-island colonisation that can result in larger effective founding population sizes than traditionally accepted colonisation mechanisms. We then test for the fit of genetic data to this model using weevils from the Laparocerus tessellatus species complex. Location: Canary Islands.

Methods: Using a combination of geological data for the Canary Islands, and mtDNA data from a weevil radiation within the Canary Islands, we test three species-level predictions for megalandslides as drivers of oceanic rafting between islands and subsequent speciation: (i) colonisation should involve multiple female lineages: (ii) founding lineages should have a common geographic origin, consistent with a mega-landslide event, and: (iii) colonisation direction should be consistent with ocean currents.

Results: Both individual-level and population-level analyses support a mega-landslide event as the driver of colonisation from the island of Tenerife to La Palma. At least four female lineages colonised La Palma from Tenerife, with the geographic range of ancestral sequences to these four lineages describing the limits of the La Orotava mega-landslide in Tenerife.

Main conclusions: In the context of island biogeographic theory, mega-landslides may be an important driver of colonisation, and subsequent lineage diversification. They provide a framework for hypothesis testing using genetic data from species, or closely related species, with ranges that encompass landslides and potential areas of colonisation.

Key words: biogeography, invertebrate, dispersal, phylogeography, equilibrium theory, rafting 
58

59

60

61

62

63

64

65

66

67

68

69

70

71

72

73

74

\section{Introduction}

Our understanding of speciation within oceanic archipelagos has advanced considerably in recent decades (Warren et al., 2015), in large part as a consequence of continued efforts to analyse phylogenetic data from a diversity of taxa with geographical, ecological and geological data. In contrast, there has been little investigation of the mechanisms promoting dispersal among islands within an archipelago, a process that underpins island biogeographic theory (MacArthur \& Wilson, 1963, 1967). Dispersal from one island to another must be either airborne or waterborne. For invertebrate taxa, which typically comprise the dominant component of species richness on oceanic islands, airborne colonisation may involve secondary transport by birds, or wind. Secondary transport by birds is likely important for ectoparasitic invertebrate taxa, or nonectoparasitic taxa transported through ingestion (e.g. Wada et al., 2011). However, transport by ingestion is unlikely to account for more than a very small proportion of invertebrate species, and likely limited to those that feed within seeds (Gillespie et al., 2012). Windborne colonisation should be important for flighted invertebrates, but less consequential for flightless invertebrates. Unless windborne colonisation involves a gravid female, a female with stored sperm, or a parthenogenetic individual, colonisation would not be followed by establishment, as it is unlikely that wind-transported individuals would arrive within the geographic proximity of each other required for subsequent mating. Even allowing for the colonisation of a multiply mated female, successful establishment of a windborne colonist could be challenging due to low genetic variation and inbreeding, although this is not always the case (e.g., see Edelaar et al., 2015). In contrast to windborne dispersal, colonisation by oceanic rafting may result in multiple individuals arriving, but is expected to involve a limited number of individuals of coastal or riverine affinity (Gillespie et al., 2012). Thus, the conceptual model of colonisation by wind or rafting is expected to result in extreme founder events, something seen as a potential driver of insular speciation (Carson \& Kaneshiro, 1976; Templeton, 1980, 2008). It is also expected to be mostly relevant for flighted species, or flightless species with coastal distributions, or with freshwater connections to the coast. Colonisation by non-coastal flightless species is harder to explain.

In their consideration of long distance dispersal (i.e. from continents to archipelagos), Gillespie et al. (2012) point out that the ability of organisms to disperse by oceanic drift, or rafting on flotsam, is a function of the interaction of four variables: (i) ocean dynamics, (ii) survival en 
89

90

91

92

93

94

95

96

97

98

99

100

101

102

103

104

105

106

107

108

109

110

111

112

113

114

115

116

117

118

119

route, (iii) geomorphology and (iv) proximity to the ocean, given that rafts are initiated from areas proximate to oceans. With regard to ocean dynamics, although they may vary through geological time, they are idiosyncratic in nature and island or archipelago specific. However, the remaining three points suggest oceanic drift or rafting may be very consequential at the inter-island scale. Regarding point (ii), the comparatively short distances between islands must greatly increase survival probability, compared to the long distances that typically characterise continental source areas and isolated oceanic archipelagos. With regard to points (iii) and (iv), oceanic island geomorphology provides for periodic, expected and large-scale deposition of biota into the ocean, spanning large altitudinal ranges, through mega-landslide events. This has the potential to promote the synchronous rafting of individuals sampled across broad geographic areas, something that could result in much larger effective founding population sizes than traditionally accepted colonisation mechanisms.

Biotic consequences of volcanic flank collapse

When volcanic edifices reach high altitudes from the ocean floor they are prone to suffer flank collapses for several reasons, principally gravitational instability, volcanic or tectonic seismicity, and dyke injections (McGuire, 2003). Areas in excess of hundreds of $\mathrm{km}^{2}$ can be affected, with flank collapse triggering substantial down slope movement of terrain, movements that can occur in only a few minutes at calculated velocities exceeding $100 \mathrm{~km} / \mathrm{h}$ (Siebert, 1984). These megalandslide events can generate ocean floor deposits of hundreds of $\mathrm{km}^{2}$, measuring hundreds of $\mathrm{km}$ in length, involving volumes in the order of thousands of $\mathrm{km}^{3}$ (Canals et al., 2000). Such megalandslides are not infrequent events, as revealed by terrestrial geological studies, sonar, threedimensional bathymetry, offshore seismic analysis, and even historical records (e.g. Ward \& Day, 2003). There is both inland and sea floor evidence for numerous mega-landslides in the Hawaiian Islands (e.g. Moore et al., 1994), Canary Islands (e.g. Carracedo et al., 2009), Réunion (e.g. Oehler et al., 2004), French Polynesian Islands (e.g. Clément et al., 2002), Tristan da Cunha Island (e.g. Holcomb \& Searle, 1991), Cape Verde Islands (e.g. Masson et al., 2008) and the Lesser Antilles Islands (e.g. Samper et al., 2008), among others. The most detailed long-term data on flank collapses within an archipelago comes from a $17 \mathrm{Myr}$ (million years) record for the Canary Islands. Hunt et al. (2014) reveal that the mean recurrence of landslides across the Canary Islands over the 
120

121

122

123

124

125

126

127

128

129

130

131

132

133

134

135

136

137

138

139

140

141

142

143

144

145

146

147

148

149

150

last $17 \mathrm{Myr}$ is $135 \mathrm{kyr}$ (thousand years), with the last $7 \mathrm{Myr}$ characterised by a similar mean recurrence of $135 \mathrm{kyr}$.

Within the Canary Islands the biggest recorded mega-landslides occurred on the island of Tenerife, with 11 documented events that affected vast areas of the island, in some cases from more than 2000 macsl (metres above current sea level) to the coast, resulting in the transfer of enormous debris deposits to the seafloor (Fig. 1, Table S1.1 in Appendix S1 in Supporting Information). While many landslides have been overwritten by subsequent lava deposits, the Orotava and Güímar valleys present clear evidence, with flat floors flanked by steep scarps defining most of their perimeter (Masson et al., 2002). The within island evolutionary significance of such landslides is well understood, as they have produced important habitat discontinuities implicated in divergent evolution between populations on opposing flanks (e.g. Brown et al., 2006; Macías-Hernández et al., 2013; Mairal et al., 2015), the biogeographic relevance of which has also been recognised (Whittaker et al., 2008). What is less understood is the fate of the vast biomass that was deposited into the ocean.

The landslide of La Orotava was initiated at sea level, followed by the rapid downslope movement of higher altitude terrains up to several hundred meters deep. During the subaerial phase of this process, maximum terrain destruction occurs at depth, with limited transformation of the surface, meaning that surface organic material likely remains relatively intact prior to entering the ocean. An obvious consequence of this dynamic would be the flotation of organic matter, derived from more than $100 \mathrm{~km}^{2}$ of diverse habitat, from the coastline to altitudes exceeding 2000 macsl (Fig. 2). Oceanic rafting on this scale, with favourable ocean currents, could potentially favour the synchronous transport of many individuals to neighbouring islands, providing a suitable scenario for testable predictions.

\section{Predictions for colonisation from a mega-landslide}

Three testable predictions can be made for the colonisation of an invertebrate species originating from a mega-landslide. The first is that colonisation should have involved multiple female lineages. The second is that founding lineages should share a common geographic origin that is spatially consistent with a mega-landslide event. The third is that colonisation direction should be consistent with ocean currents. Here we evaluate evidence for these predictions using mtDNA 
151 sequence data for a complex of flightless beetle species on the Canary Islands. Among the more 152 than 128 species within the weevil genus Laparocerus in the Canary Islands, the L. tessellatus 153 complex comprises 11 taxonomically described species, each being a single island endemic. A 154 recent molecular genetic analysis of the complex (Faria et al., 2016) sampled nine species (two 155 new species were subsequently described by Machado, 2016) revealed complex relationships 156 among individual-level patterns of nuclear and mtDNA sequence relatedness, and taxonomy (see 157 Faria et al., 2016 for details). Of relevance to the above-mentioned predictions, it was revealed 158 that the single species from the island of La Palma was founded by individuals of related species 159 from the islands of Tenerife and Gran Canaria (Faria et al., 2016). In the case of Tenerife, two 160 founding mtDNA haplotypes to La Palma were inferred from sequences sampled from several 161 localities above the steep scarps defining the perimeter of the Orotava valley. This provides a 162 minimum estimate of two colonising female lineages, and is suggestive of a possible role for the La 163 Orotava mega-landslide. We evaluate this hypothesis by sampling the L. tessellatus complex to 164 specifically test the prediction of multiple founding female lineages to La Palma from the region of 165 the Orotava valley. We use DNA sequence data from the mitochondrial genome, as its 166 characteristic female inheritance and absence of recombination allows for robust inferences of the 167 minimum number of founding female lineages through the reconstruction of coalescent ancestry. 168 169 170 Materials and Methods

171

Sampling and laboratory procedures

173 174 175 176

We increased previous geographic sampling for the L. tessellatus complex (Faria et al., 2016) by visiting collecting localities for species of the L. tessellatus complex within the collection of AM, and several other new localities. From two to five individuals were sequenced from each locality on the island of Gran Canaria. As our focus is on the mtDNA relatedness between La Palma and Tenerife, we took an iterative approach to sequencing. Two individuals from each sampling locality were sequenced in the first instance for the mtDNA COIl gene region for joint analysis with published data (Faria et al., 2016). Localities in Tenerife yielding mtDNA sequences closely related to La Palma were then sequenced for a further three individuals (unless limited by sample 
182

183

184

185

186

187

188

189

190

191

192

193

194

195

196

197

198

199

200

201

202

203

204

205

206

207

208

209

210

211

212

numbers). Similarly, all localities in La Palma with mtDNA sequences closely related to sequences from Tenerife were sequenced for a further three individuals. Total genomic DNA was extracted from the two hind legs using a Chelex extraction protocol (Casquet et al., 2012). The mitochondrial COIl gene was amplified using previously described conditions (Faria et al., 2016) and sequenced using the Sanger DNA sequencing service of Macrogen (www.macrogen.com). Sequences were edited with Geneious R8 8.0.3 (http://geneious.com, Kearse et al., 2012), aligned using MEGA 6.06 (Tamura et al., 2013), and unique haplotypes were collapsed Fabox 1.41 (Villesen, 2007).

\section{Haplotype network and Bayesian phylogenetic tree construction}

Statistical parsimony was used to infer a haplotype network using PopART (Leigh \& Bryant, 2015). Predictions from coalescent theory, related to the frequency and geographical distribution of haplotypes, are often applied to resolve reticulations within haplotype networks (Posada \& Crandall, 2001). However, the strong geographic structuring of mtDNA variation within the $L$. tessellatus complex (Faria et al., 2016) precludes the use of probability-based predictions derived from coalescent theory to solve reticulations (Posada \& Crandall, 2001). We therefore used an alternative probability-based approach where, for each reticulation, we evaluated alternative solutions under an appropriate model of DNA sequence evolution. This was achieved by constructing a Bayesian tree from the sequence data with MrBayes v3.2.5 (Ronquist, 2012) under a general time reversible model of sequence evolution with a gamma correction (GTR+G) without modelling invariant sites (I), as in Faria et al. (2016). Four analyses were each run for 100 million generations using $4 \mathrm{MCMC}$ (Markov chain Monte Carlo) chains, starting from a random tree, and sampling trees every 1000 generations. For both the network and Bayesian analyses a sequence from the closely related species $L$. vicinus was used as an outgroup. Stationarity and convergence of the chains were determined by graphical inspection of the values of the log-likelihoods of the four MCMC analyses; confirmation that the average standard deviation of split frequencies was below 0.01 at the completion of the analysis; and verification that effective sample size (ESS) values were above 200 using the log files in Tracer 1.6 (Rambaut, 2016). A burn-in of 25\% was removed from each run, and the remaining trees were used to construct a majority-rule consensus tree. 
213

214

215

216

217

218

219

220

221

222

223

224

225

226

227

228

229

230

231

232

233

234

235

236

237

238

239

240

241

242

243

Minimum estimation of founding female lineages

We used a rooted haplotype network of geographically referenced mtDNA sequences, to infer the dispersal history of maternal lineages (e.g. Emerson et al., 2006). The rooted mtDNA haplotype network was used to estimate the minimum number of mtDNA haplotypes that are, or have been, shared between islands, with the direction of dispersal inferred from the order of geographic state change from the root of the network (Fig. 3). This provides a minimum estimate of the number of female lineages that have dispersed between islands. One or more geographic states (islands) can be assigned to each sampled haplotype, and on the basis of these known states, one can infer the geographic states of missing (extinct or unsampled) haplotypes within the network. We inferred haplotype sharing (female dispersal) either (i) directly, when a sampled haplotype had two geographic states (Fig. 3A), or (ii) indirectly, when the geographic state changed between an ancestral and descendent haplotype (Fig. 3B-F).

\section{Analyses of population structure}

We defined three geographic regions based upon the relatedness of mtDNA haplotypes between La Palma and Tenerife. The first region consists of all sites on La Palma sampled for mtDNA lineages derived from Tenerife. The second region is a polygon describing the minimum geographic range of mtDNA haplotypes and their descendants from Tenerife that are ancestral to La Palma haplotypes. To construct the polygon we applied an iterative approach, using the minimum convex polygon method (Mohr, 1947). In a first iteration a polygon describing the geographic range of this group of haplotypes was constructed. Subsequent iterations removed haplotypes from populations at the periphery of the polygon if they were also present within interior population, until no more haplotypes could be removed. The third region comprises the remaining sampling sites on Tenerife that fall outside the polygon.

To test whether the distribution of mtDNA genetic diversity reveals a phylogeographic pattern within the $L$. tessellatus complex distributed across the three regions, genetic differentiation among populations was estimated using both $F_{S T}$ (genetic distance among haplotypes is unweighted) and $\mathrm{N}_{S T}$ (genetic distance among haplotypes is weighted). When mutation rate exceeds dispersal rate, haplotypes within regions will be more closely related than 
244

245

246

247

248

249

250

251

252

253

254

255

256

257

258

259

260

261

262

263

264

265

266

267

268

269

270

271

272

273

274

haplotypes compared among regions (Pons \& Petit, 1996). Under these conditions $\mathrm{N}_{S T}$ will exceed $\mathrm{F}_{S T}$, indicating a greater role of mutation and the phylogeographic structuring of genetic variation over evolutionary time scales, compared to the structuring of genetic variation by gene flow and genetic drift over ecological time scales. To test whether $\mathrm{N}_{S T}$ was significantly higher than $\mathrm{F}_{S T}$, a randomization procedure permuting haplotype assignation in the matrix of genetic distances among haplotypes was performed and repeated 10,000 times in SPaGeDi 1.4b (Hardy \& Vekemans, 2002).

\section{Results}

Haplotype network and Bayesian phylogenetic tree

Forty-seven sites were sampled in Tenerife, 32 in La Palma, and 21 in Gran Canaria (Fig. 4, Table S2.2 in Appendix S2). A total of 255 new individuals were sequenced, yielding 394 DNA sequences together with previously published sequences (Faria et al., 2016). DNA sequences were collapsed to 195 unique haplotypes, characterised by 164 polymorphic sites across 633 bp, 127 of which were parsimony informative. A single haplotype network was obtained from the statistical parsimony analysis, with a total of 44 reticulations, of which all but two were solved with the Bayesian phylogenetic reconstruction (Fig. S2.1 in Appendix S2). The resolved network (Fig. 5) thus presents comparable geographic clusters of sequences, branching relationships among them, and root location, as those obtained in the Bayesian phylogenetic analysis (Fig. S2.1 in Appendix S2).

\section{Number and origin of founding female lineages from Tenerife to La Palma}

The rooted haplotype network reveals that the mtDNA variation of the L. tessellatus complex across the four islands has involved the establishment of at least 11 female lineages by inter-island colonisation (Fig. 5). Our sampling reveals a total of six colonising haplotypes to the island of La Palma, doubling a previous estimate (Faria et al., 2016), of which two are derived from Gran Canaria, with the remaining four derived from Tenerife. Twenty mtDNA haplotypes from Tenerife were identified either as ancestral to La Palma (2), or derived from ancestral haplotypes (18) by no 
275

276

277

278

279

280

281

282

283

284

285

286

287

288

289

290

291

292

293

294

295

296

297

298

299

300

301

302

303

304

305

more than 4 mutations (Fig. 5) and were sampled from 18 of the 47 sampling sites. For ease of understanding we refer to these as TF-LP haplotypes. The mean divergence between the 18 derived TF-LP haplotypes and the most closely related sampled or unsampled ancestral haplotype was 1 mutation. A polygon describing the minimum geographic range of the 20 TF-LP haplotypes was arrived at after 4 iterations, and included a total of 18 sampling sites, 14 of which contain TFLP haplotypes, which broadly describes the Orotava valley (Fig. 4). All but two of the 18 sites are above the steep escarpments or within the Orotava valley, with the remaining two sites on the geographically proximate southern slope of the Güimar valley. The 18 sampling sites within the polygon were sampled for a total of 80 individuals, of which 49 presented a TF-LP haplotype, with the remaining 31 presenting one of the 18 other haplotypes sampled within this region. The remaining 29 Tenerife sampling sites outside the polygon were sampled for a total of 89 individuals and 39 haplotypes.

The global $\mathrm{N}_{S T}$ of 0.34 is significantly higher $(\mathrm{P}<0.001)$ than the global $\mathrm{F}_{S T}$ of $0.03(\mathrm{P}<0.001)$, indicating the dominant role of geographic isolation and mutation over gene flow and genetic drift for the structuring of genetic variation across the three regions. All pairwise $\mathrm{F}_{S T}$ and $\mathrm{N}_{S T}$ comparisons are significantly different from zero and $\mathrm{N}_{S T}$ were consistently significantly higher than $F_{S T}(P<0.001 ;$ Table 1). The two regions of Tenerife are the least differentiated from each other. La Palma is similarly differentiated from the Orotava valley and all other Tenerife sampling sites for $\mathrm{F}_{S T}$ (0.04 for both), but less differentiated from the polygon representing the Orotava valley for $\mathrm{N}_{S T}$ ( 0.38 from the Orotava valley and 0.45 from the rest of Tenerife). Thus, mtDNA variation in La Palma is less differentiated from mtDNA variation in the Orotava valley than it is from the rest of Tenerife, supporting the hypothesis that the Orotava valley is the source area for individuals that colonised La Palma.

\section{Discussion}

In support of predictions one and two, we find that multiple founding individuals to La Palma share a common geographic origin consistent with the mega-landslide event of the Orotava valley. Marine currents between Tenerife and La Palma provide support for prediction three. The Canary Current is estimated to have been relatively unchanged over the past $22 \mathrm{Myr}$, passing southward 
306

307

308

309

310

311

312

313

314

315

316

317

318

319

320

321

322

323

324

325

326

327

328

329

330

331

332

333

334

335

336

along the northwest African coast, until reaching the Canary Islands, the geomorphology of which forces it to pass among the islands. Of particular relevance is the trade wind season which results in currents that flow to the south between islands, but also an offshore current that swings around the archipelago (Mittelstaedt, 1991), providing a connection between Tenerife and La Palma. The Canary Current has an estimated flow speed of $10-30 \mathrm{~cm} \cdot \mathrm{s}^{-1}$ (Wooster et al., 1976), suggesting that the offshore current would carry floating organic material deposited from the Orotava valley over the minimum distance of $120 \mathrm{~km}$ between the coast of La Orotava and the coast of La Palma in a period between 4 and 13 days.

Mega-landslide, or small raft?

Rafts of vegetation are recognised as an important mechanism for the arrival of species to oceanic islands from more distant continental source areas, and rafts of a similar nature are also likely to play a role in inter-island colonisation. However, as highlighted by Gillespie et al. (2012), such rafts will be initiated from areas proximate to oceans (e.g. coastal areas, or upriver), and are thus more relevant for flora and fauna of coastal or riverine affinity. The L. tessellatus complex in Tenerife is typical of altitudes between 764 macsl and 1424 macsl (first and third quartiles of species distribution records), and is rarely observed below an altitude of 300 macsl (see Appendix S3), meaning that transportation by rafts, in the classical sense of coastal or freshwater origin, is improbable. In contrast, a landslide event on the scale of that forming the Orotava Valley would yield rafting organic matter from higher altitudes (Fig. 2). There is little direct data on what would happen to this organic matter once it enters the sea, but an important insight comes from the eruption of Mount St. Helens in May 1980. The eruption itself was preceded, and probably in part promoted, by a mega-landslide that carried tens of thousands of trees into Spirit Lake, where a giant log raft formed and persisted for years (Coffin, 1983; see Appendix S3). The behaviour of the Mount St. Helens landslide highlights the potential for large scale oceanic rafting of organic material derived from a mega-landslide. For the Orotava landslide, the estimated surface area 136 $\mathrm{km}^{2}$ (Table S1.1 in Appendix S1), would have contributed many millions of individual plants and invertebrates to floating organic matter. 
337 338 339 340 341

Mega-landslides, tsunamis, and their consequences for island biogeography

Mega-landslides from volcanic island flank collapses are expected to directly deposit a large amount of organic material into the ocean (Fig. 2). An additional consequence of such landslide events is that they also trigger tsunamis when entering energetically into the sea (McGuire, 1996), and there are records of tsunamis from landslides in recent times (Evans et al., 2006; Furukawa et al., 2008 and references therein), as well as coastal deposits for more historical events (e.g. McMurtry et al., 1999; McMurtry et al., 2004b; Pérez-Torrado et al., 2006; Coello et al., 2014; Ramalho et al., 2015). The resulting tsunami waves are propagated both offshore and onshore (Didenkulova et al., 2010; Sue et al., 2011), and can reach heights of hundreds of metres, as recorded by coastal deposits (e.g. McMurtry et al., 2004b: 240-356 m; McMurtry et al., 2004a: 400 m; Pérez-Torrado et al., 2006: 188 m; Ramalho et al., 2015: 270 m). Thus, tsunamis not only wash up the coasts of islands and mainland areas in their trajectory, but also the coast of the island suffering the landslide.

Given that there are both offshore and onshore tsunami waves propagating from a megalandslide (Didenkulova et al., 2010; Sue et al., 2011), deposition of organic material into the ocean is also expected from (i) areas of the source island affected by the onshore tsunami, and (ii) islands impacted by the offshore tsunami. Thus, mega-landslides are expected to promote the ocean deposition and rafting of significantly more organic material than that associated with the landslide itself, although the altitude of secondary deposition will be a function of the tsunami height. In the context of island biogeographic theory, for which colonisation is a fundamental component (MacArthur \& Wilson, 1963, 1967), mega-landslides may be an important driver of colonisation, mediated by ocean currents and archipelago geomorphology.

\section{Limitations and further considerations}

A general limitation that applies to the present study is a lack of power to estimate the timing of colonisation of mtDNA lineages, which are expected to be synchronous when driven by a megalandslide event, and consistent with the timing of the mega-landslide event. This is because the estimation of colonisation times of mtDNA lineages that are derived from coalescent mtDNA variation within a source population is subject to multiple sources of error, including unsampled or 
368

369

370

371

372

373

374

375

376

377

378

379

380

381

382

383

384

385

386

387

388

389

390

391

392

393

extinct haplotypes (see Fig. 5, and Fig. 2 for a conceptual explanation), mean substitution rate uncertainty and high rate variance over a coalescent time-scale. We suggest that some of these challenges may be alleviated in future studies with reduced representation genome sequencing approaches, such as restriction site-associated DNA sequencing (RADseq). With access to geographically referenced patterns of relatedness across potentially thousands of nuclear loci, it may be possible to estimate demographic parameters such as the number of founding events, their timing, and their founding population size(s).

For a given mega-landslide event, ocean currents and archipelago geomorphology will influence the dispersal of organic material deposited into the ocean, potentially providing for model-based hypothesis testing. However, obtaining supporting evidence is expected to be challenging for older mega-landslide events. This is because lineage sorting will erode patterns of shared genetic variation across islands with time, until all individuals coalesce back to a single source lineage. Thus, the older a landslide event is, the less likely it will be to find signatures of colonisation involving multiple individuals. We therefore suggest that it will be advantageous to investigate mega-landslides of recent geological origin. Given the potential for mega-landslides to result in the synchronous colonisation of a large number species to a neighbouring island, we also suggest sampling multiple species with distributions that could be explained by a mega-landslide. Taking a multi-species, multi-locus approach, with a focus on geologically recent mega-landslides should shed light on their general importance in oceanic island biogeography. 
1

2

3

4

5

6

7

8

9

10

\section{Acknowledgements}

395 We thank the following for assistance with field sampling: Antonio Perez Delgado, Antonia Salces 396 Castellano, Alessia Giarola, Michael Hickerson, and Rafael García. We thank Elena Morales for 397 assistance with the estimation of potential vegetation affected by landslides in Tenerife. Fieldwork 398 was supported by permits granted by the Cabildo of La Palma (No. ref. A/EST-020/2014), the 399 Cabildo of Gran Canaria (No. exp.: 167/15), and the Cabildo of Tenerife (No. sigma: 2015-00218).

400 We are also grateful to the Cabildo of La Palma for providing accommodation. This work was 401 supported by Spanish MINECO grant CGL2013-42589-P, co-financed by FEDER. VGO is funded by a 402 Spanish MINECO FPI contract and JP is funded by a Spanish MINECO Fellowship (Juan de la Cierva 403 Program - Incorporation); IJCI-2014-19691. We also thank two anonymous referees for helpful 404 comments and suggestions on an earlier version of the manuscript. 405 
406

407

408

409

410

411

412

413

414

415

416

417

418

419

420

421

422

423

424

425

426

427

428

429

430

431

432

433

434

435

436

437

438

439

440

441

442

443

444

445

446

447

448

449

450

\section{References}

Brown, R.P., Hoskisson, P.A., Welton, J.H. \& Báez, M. (2006) Geological history and within-island diversity: a debris avalanche and the Tenerife lizard Gallotia galloti. Molecular Ecology, 15, 3631-3640.

Brullé, G.A. (1839) Insectes. Histoire naturelle des îles Canaries (ed. by P.B. Webb and S. Berthelot), pp. 54-95. Bethune, Paris.

Canals, M., Urgeles, R., Masson, D. \& Casamor, J.L. (2000) Los deslizamientos submarinos de las Islas Canarias. Makaronesia: Boletín de la Asociación de Amigos del Museo de Ciencias Naturales de Tenerife, 2, 57-69.

Carracedo, J.C., Pérez-Torrado, F.J., Paris, R. \& Rodríguez, E. (2009) Megadeslizamientos en las Islas Canarias. Enseñanza de las Ciencias de la Tierra, 17, 44-56.

Carson, H.L. \& Kaneshiro, K.Y. (1976) Drosophila of Hawaii: systematics and ecological genetics. Annual Review of Ecology and Systematics, 7, 311-345.

Casquet, J., Thebaud, C. \& Gillespie, R.G. (2012) Chelex without boiling, a rapid and easy technique to obtain stable amplifiable DNA from small amounts of ethanol-stored spiders. Molecular Ecology Resources, 12, 136-141.

Clément, J.-P., Legendre, C., Caroff, M., Guillou, H., Cotten, J., Bollinger, C. \& Guille, G. (2002) Epiclastic deposits and 'horseshoe-shaped' calderas in Tahiti (Society Islands) and Ua Huka (Marquesas Archipelago), French Polynesia. Journal of Volcanology and Geothermal Research, 120, 87-101.

Coello, J.J., Martín, E. \& Hernández Gutiérrez, L. (2014) Depósitos de tsunami originados por un deslizamiento gravitacional masivo en Tenerife (Islas Canarias). Vieraea, 42, 79-102.

Coffin, H.G. (1983) Erect floating stumps in Spirit Lake, Washington. Geology, 11, 298-299.

Didenkulova, I., Nikolkina, I., Pelinovsky, E. \& Zahibo, N. (2010) Tsunami waves generated by submarine landslides of variable volume: analytical solutions for a basin of variable depth. Natural Hazards and Earth System Science, 10, 2407-2419.

Edelaar, P., Roques, S., Hobson, E.A., Gonçalves da Silva, A., Avery, M.L., Russello, M.A., Senar, J.C., Wright, T.F., Carrete, M. \& Tella, J.L. (2015) Shared genetic diversity across the global invasive range of the monk parakeet suggests a common restricted geographic origin and the possibility of convergent selection. Molecular Ecology, 24, 2164-2176.

Emerson, B.C., Forgie, S., Goodacre, S.L. \& Oromi, P. (2006) Testing phylogeographic predictions on an active volcanic island: Brachyderes rugatus (Coleoptera: Curculionidae) on La Palma (Canary Islands). Molecular Ecology, 15, 449-458.

Evans, S.G., Scarascia Mugnozza, G., Strom, A.L., Hermanns, R.L., Ischuk, A. \& Vinnichenko, S. (2006) Landslides from massive rock slope failure and associated phenomena. Landslides from Massive Rock Slope Failure (ed. by S.G. Evans, G. Scarascia Mugnozza, A.L. Strom and R.L. Hermanns), pp. 3-52. Springer, Netherlands.

Faria, C.M.A., Machado, A., Amorim, I.R., Gage, M.J.G., Borges, P.A.V. \& Emerson, B.C. (2016) Evidence for multiple founding lineages and genetic admixture in the evolution of species within an oceanic island weevil (Coleoptera, Curculionidae) super-radiation. Journal of Biogeography, 43, 178-191.

Furukawa, R., Nanayama, F. \& Yoshimoto, M. (2008) Volcanic Debris-Avalanche as a Cause of a Historic Tsunami: The AD 1640 Eruption of the Hokkaido-Komagatake Volcano, Northern Japan. Solutions to Coastal Disasters 2008 (ed by L. Wallendorf, L. Ewing, C. Jones and B. Jaffe), pp. 235-247. Turtle Bay, Oahu, Hawaii. 
451

452

453

454

455

456

457

458

459

460

461

462

463

464

465

466

467

468

469

470

471

472

473

474

475

476

477

478

479

480

481

482

483

484

485

486

487

488

489

490

491

492

493

494

495

Gillespie, R.G., Baldwin, B.G., Waters, J.M., Fraser, C., Nikula, R. \& Roderick, G.K. (2012) Longdistance dispersal - a framework for hypothesis testing. Trends in Ecology \& Evolution, 27, 47-56.

Hardy, O.J. \& Vekemans, X. (2002) SPAGeDi: a versatile computer program to analyse spatial genetic structure at the individual or population levels. Molecular Ecology Notes, 2, 618620.

Holcomb, R.T. \& Searle, R.C. (1991) Large landslides from oceanic volcanoes. Marine Georesources \& Geotechnology, 10, 19-32.

Hunt, J.E., Talling, P.J., Clare, M.A., Jarvis, I. \& Wynn, R.B. (2014) Long-term (17Ma) turbidite record of the timing and frequency of large flank collapses of the Canary Islands. Geochemistey, Geophysics, Geosystems, 15, 3322-3345.

Kearse, M., Moir, R., Wilson, A., Stones-Havas, S., Cheung, M., Sturrock, S., Buxton, S., Cooper, A., Markowitz, S., Duran, C., Thierer, T., Ashton, B., Mentjies, P. \& Drummond, A.J. (2012) Geneious Basic: an integrated and extendable desktop software platform for the organization and analysis of sequence data. Bioinformatics, 28, 1647-1649.

Leigh, J.W. \& Bryant, D. (2015) Popart: Full-Feature Software for Haplotype Network Construction. Methods in Ecology and Evolution, 6, 1110-1116.

Lindberg, H. (1953) Zweiter Beitrag zur Kenntnis der Käferfauna der Kanarischen Inseln. Commentationes Biologicae, 13, 1-8.

MacArthur, R.H. \& Wilson, E.O. (1963) An equlilbrium theory of insular zoogeography. Evolution, 17, 373-387.

MacArthur, R.H. \& Wilson, E.O. (1967) The theory of island biogeography. Princeton University Press, Princeton.

Machado, A. (2011) Nuevos taxones de Laparocerus Schoenherr, 1834 de El Hierro y La Gomera, Islas Canarias (Coleoptera, Curculionidae, Entiminae). Graellsia, 67, 57-90.

Machado, A. (2012) Nuevos taxones de Laparocerus Schoenherr, 1834 de la isla de Gran Canaria (Coleoptera, Curculionidae, Entiminae). Boletín de la Sociedad Entomológica Aragonesa, 51, 5-46.

Machado, A. (2016) Laparocerus Schoenherr, 1834 nuevos de Canarias y claves de las especies de la isla de Tenerife (Coleoptera, Curculionidae, Entiminae). Graellsia, 72, e049.

Macías-Hernández, N., Bidegaray-Batista, L., Emerson, B.C., Oromí, P. \& Arnedo, M.A. (2013) The imprint of geologic history on within-island diversification of woodlouse-hunter spiders (Araneae, Dysderidae) in the Canary Islands. Journal of Heredity, 104, 341-356.

Mairal, M., Sanmartín, I., Aldasoro, J., Culshaw, V., Manopoulou, I. \& Alarcón, M. (2015) Palaeoislands as refugia and sources of genetic diversity within volcanic archipelagos: the case of the widespread endemic Canarina canariensis (Campanulaceae). Molecular Ecology, 24, 3944-3963.

Masson, D., Le Bas, T., Grevemeyer, I. \& Weinrebe, W. (2008) Flank collapse and large-scale landsliding in the Cape Verde Islands, off West Africa. Geochemistry, Geophysics, Geosystems, 9, Q07015.

Masson, D., Watts, A., Gee, M., Urgeles, R., Mitchell, N., La Bas, T. \& Canals, M. (2002) Slope failures on the flanks of the western Canary Islands. Earth-Science Reviews, 57, 33-45.

McGuire, W. (2003) Volcano instability and lateral collapse. Revista, 1, 33-45.

McGuire, W.J. (1996) Volcano instability: a review of contemporary themes. Geological Society London Special Publications, 110, 1-23. 
496

497

498

499

500

501

502

503

504

505

506

507

508

509

510

511

512

513

514

515

516

517

518

519

520

521

522

523

524

525

526

527

528

529

530

531

532

533

534

535

536

537

538

539

540

541

McMurtry, G., Watts, P., Fryer, G., Smith, J. \& Imamura, F. (2004a) Giant landslides, megatsunamis, and paleo-sea level in the Hawaiian Islands. Marine Geology, 203, 219-233.

McMurtry, G., Fryer, G., Tappin, D.R., Wilkinson, I.P., Williams, M., Fietzke, J., Garbe-Schoenberg, D. \& Watts, P. (2004b) Megatsunami deposits on Kohala volcano, Hawaii, from flank collapse of Mauna Loa. Geology, 32, 741-744.

McMurtry, G.M., Herro-Bervera, E., Cremer, M.D., Smith, J.R., Resig, J., Sherman, C. \& Torresan, M.E. (1999) Stratigraphic constraints on the timing and emplacement of the Alika 2 giant Hawaiian submarine landslide. Journal of Volcanology and Geothermal Research, 94, 35-58.

Mittelstaedt, E. (1991) The ocean boundary along the northwest African coast: Circulation and oceanographic properties at the sea surface. Progress in Oceanography, 26, 307-355.

Mohr, C.O. (1947) Table of equivalent populations of North American small mammals. American Midland Naturalist, 37, 223-249.

Moore, J.G., Normark, W.R. \& Holcomb, R.T. (1994) Giant hawaiian landslides. Annual Review of Earth and Planetary Sciences, 22, 119-144.

Oehler, J.-F., Labazuy, P. \& Lénat, J.-F. (2004) Recurrence of major flank landslides during the last 2-Ma-history of Reunion Island. Bulletin of Volcanology, 66, 585-598.

Pérez-Torrado, F.J., Paris, R., Cabrera, M.C., Schneider, J.-L., Wassmer, P., Carracedo, J.C., Rodríguez-Santana, Á. \& Santana, F. (2006) Tsunami deposits related to flank collapse in oceanic volcanoes: the Agaete Valley evidence, Gran Canaria, Canary Islands. Marine Geology, 227, 135-149.

Pons, O. \& Petit, R.J. (1996) Measuring and testing genetic differentiation with ordered versus unordered alleles. Genetics, 144, 1237-1245.

Posada, D. \& Crandall, K.A. (2001) Intraspecific gene genealogies: trees grafting into networks. Trends in Ecology and Evolution, 16, 37-45.

Ramalho, R.S., Winckler, G., Madeira, J., Helffrich, G.R., Hipólito, A., Quartau, R., Adena, K. \& Schaefer, J.M. (2015) Hazard potential of volcanic flank collapses raised by new megatsunami evidence. Scientific Advances, 1, e1500456.

Rambaut, A. (2016) FigTree v1.4.3, Available from http://tree.bio.ed.ac.uk/software/figtree/.

Ronquist, F., M. Teslenko, P. van der Mark, D. L. Ayres, A. Darling, S. Hohna, B. Larget, L. Liu, M. A. Suchard, J. P. Huelsenbeck (2012) MrBayes 3.2: Efficient bayesian phylogenetic inference and model choice across a large model space. Systematic Biology, 61, 539-542.

Samper, A., Quidelleur, X., Boudon, G., Le Friant, A. \& Komorowski, J. (2008) Radiometric dating of three large volume flank collapses in the Lesser Antilles Arc. Journal of Volcanology and Geothermal Research, 176, 485-492.

Siebert, L. (1984) Large volcanic debris avalanches: characteristics of source areas, deposits, and associated eruptions. Journal of Volcanology and Geothermal Research, 22, 163-197.

Sue, L., Nokes, R. \& Davidson, M. (2011) Tsunami generation by submarine landslides: comparison of physical and numerical models. Environmental fluid mechanics, 11, 133-165.

Tamura, K., Stecher, G., Peterson, D., Filipski, A. \& Kumar, S. (2013) MEGA6: Molecular Evolutionary Genetics Analysis Version 6.0. Molecular Biology and Evolution 30, 2725-2729.

Templeton, A.R. (1980) The theory of speciation via the founder principle. Genetics, 94, 1011-1038.

Templeton, A.R. (2008) The reality and importance of founder speciation in evolution. Bioessays, 30, 470-479.

Uyttenboogaart, D.L. (1940) Voyages de M. Ch. Alluaud aux lles Canaries (1889-90) et à l'archipel de Madère (1938). Coléoptères Curculionides. Revue Française d'Entomologie, Paris, 7, 4969. 
542

543

544

545

546

547

548

549

550

551

552

553

554

555

556

557

558

559

560

561

562

563

564

565

566

567

568

569

570

571

572

573

574

575

576

577

Villesen, P. (2007) Fabox: An online fasta sequence toolbox. Molecular Ecology Notes, 7, 965-968.

Wada, S., Kawakami, K. \& Chiba, S. (2011) Snails can survive passage through a bird's digestive system. Journal of Biogeography, 39, 69-73.

Ward, S.N. \& Day, S. (2003) Ritter Island Volcano-lateral collapse and the tsunami of 1888. Geophysical Journal International, 154, 891-902.

Warren, B.H., Simberloff, D., Ricklefs, R.E., Aguilée, R., Condamine, F.L., Gravel, D., Morlon, H., Mouquet, N., Rosindell, J., Casquet, J., Conti, E., Cornualt, J., Fernández-Palacios, J.M., Hengl, T., Norder, S.J., Rijsdijk, K.F., Sanmartín, I., Strasberg, D., Triantis, K.A., Valente, L.M., Whattaker, R.J., Gillespie, R.G., Emerson, B.C. \& Thébaud, C. (2015) Islands as medel systems in ecology and evolution: fifty years after MacArthur-Wilson. Ecology Letters, 18, 200-217.

Whittaker, R.J., Triantis, K.A. \& Ladle, R.J. (2008) A general dynamic theory of oceanic island biogeography. Journal of Biogeography, 35, 977-994.

Wollaston, T.V. (1864) Catalogue of the coleopterous insects of the Canaries in the collection of the British Museum. Taylor \& Francis, London.

Wooster, W.S., Bakum, A. \& McLain, D.R. (1976) The seasonal upwelling cycle along the eastern boundary of the North Atlantic. Journal of Marine Research, 34, 131-140.

\section{Supporting information}

Additional supporting Information includes one figure and three tables and can be found with this article:

Appendix S1: Details of documented landslides in the island of Tenerife

Appendix S2: Details of sampling locations and the taxonomic assignment of samples, and the Bayesian phylogenetic tree constructed from 194 unique mtDNA haplotypes.

Appendix S3: Altitudinal sampling data for the L. tessellatus complex in Tenerife, and photographic evidence of floating vegetation resulting from the 1980 eruption of Mount St. Helens.

\section{Data accessibility}

The accession number for the DNA sequence alignment reported in this paper is Dryad: http://to_be_included_upon_acceptance.

\section{Biosketch}

The research team have complementary interests in the geology and biodiversity of oceanic islands, and the application of molecular data to understand the origin and maintenance of species and communities of species. This work is a synthesis of these different interests. 
578 Author contributions: BCE, VGO and HL conceived and coordinated the study with input from JP, 579 NA, AM, JCC and VS. BCE, VGO and HL undertook the fieldwork, with input from AMC. VGO carried 580 out all laboratory procedures and data analysis, with input from BCE, HL and JP. VGO, HL and BCE 581 wrote the paper with input from other authors.

582

583 Editor: Kostas Triantis

584

585 
1

2

3

4

5

6

7

8

9

10

586 Table 1. Pairwise $F_{\text {ST }}$ (below) and $N_{\text {ST }}$ (above) values calculated using mtDNA COIl sequence data 587 for the Laparocerus tessellatus complex sampled from the Orotava Valley, Tenerife (excluding the 588 Orotava valley) and La Palma. P-values indicate the probability that $F_{S T}$ is significantly different 589 from zero after 10.000 permutations of specimens among the three regions. P-values for $N_{\text {ST }}$ 590 indicate the probability that $N_{\mathrm{ST}}$ is significantly different from $F_{\mathrm{ST}}$ after 10.000 permutations of the 591 matrix of genetic distances among haplotypes.

592

\begin{tabular}{cccc}
\hline & Orotava Valley & Tenerife & La Palma \\
Orotava Valley & - & $0.130^{* * *}$ & $0.377^{* * *}$ \\
Tenerife & $0.022^{* * *}$ & - & $0.452^{* * *}$ \\
La Palma & $0.042^{* * *}$ & $0.041^{* * *}$ & - \\
\hline
\end{tabular}

593

$594 * * * \mathrm{P}<0.001$

595 
600

601

602

603

604

605

606

607

608

609

610

611

612

613

614

615

616

617

618

619

620

621

622

623

624

625

626

Figure 1. Mega-landslides on the island of Tenerife. Seven of the 11 documented landslides are sufficiently unaffected by subsequent volcanic activity to be able to identify their geographic limits. Landslides are colour-coded according to the inset that provides approximate ages for each megalandslide. See Table S1.1 in Appendix S1 for more details.

Figure 2. Biotic consequences of a volcanic flank collapse. (A) Flank collapse is initiated near sealevel, causing the downslope movement of a block of terrain. The surface of the affected terrain suffers limited transformation, with maximum transformation occurring along the sliding plane. (B) A consequence of the dynamic described in $A$ is that much of the organic surface layer may enter in the ocean practically intact, with a high proportion remaining on the surface due to its high floatability. (C) The ocean surface will contain a vast amount of organic debris derived from the surface of the landslide, including living animals and plant material. This flotsam, together with favourable winds and marine currents, would favour the dispersal of animals and plant species between islands.

Figure 3. Inferring sets of potential colonist (geographically shared) haplotypes, and the minimum number of colonising haplotypes. Haplotypes from an ancestral island (X) are represented as black filled circles. Haplotypes from a colonised island (Y) are represented as white filled circles. Haplotypes found on both $X$ and $Y$ are shown in hatching. Large circles represent sampled haplotypes. Small circles represent missing (extinct or unsampled) haplotypes, whose potential geographic states are inferred based on the known geographic states of immediately ancestral and descendent sampled haplotypes. For each of the scenarios A-G, asterisks indicate the set of haplotypes from which a minimum of one haplotype is inferred to have colonised from $X$ to $\mathrm{Y}$. (A) represents no haplotype extinction and sampling of all haplotypes, while C-E represent the same scenario but with some extinct or unsampled haplotypes, while F-G represent alternative scenarios with coalescence. (A) 5 is identified as the colonising haplotype as it is shared across both islands. (B) Either 4 or 5 is the colonising haplotype: 4 colonised $Y$ and is unsampled or extinct on $Y$, or 5 colonised $Y$ and is unsampled or extinct on $X$. (C) Either 5 or 6 is the colonising haplotype: 5 colonised $Y$ and is unsampled or extinct on $Y$, or 6 colonised $Y$ and is unsampled or extinct on X. (D) Either 4, 5 or 6 is the colonising haplotype: 4 colonised $Y$ and is unsampled or extinct on $Y$, or 5 colonised $Y$ and is unsampled or extinct on both islands, or 6 colonised $Y$ and is 
627 unsampled or extinct on $X$. (E) Any of haplotypes 2-9 may have colonised from $X$ to $Y$ : 2 colonised $Y$ 628 and is unsampled or extinct on $\mathrm{B}$, or one of haplotypes 3-8 colonised $\mathrm{Y}$ and is unsampled or extinct 629 on both islands, or 9 colonised $Y$ and is unsampled or extinct on $X$. (F) At least two colonising 630 haplotypes are inferred, due to the sampling of haplotypes 2 and 10 on $X$, with a minimum of one 631 shared haplotype between haplotypes 2-9, and the other between 10-17. (G) Similar to F, but 632 unsampled or extinct haplotypes 2 and 10 result in a minimum inference of 1 colonising haplotype.

633 634 Figure 4. Map of sampling sites for the Laparocerus tessellatus complex. The eleven 635 636 taxonomically defined species within the complex are all single island endemics. Gran Canaria (5 species): L. microphthalmus Lindberg, 1950, L. obsitus Wollaston, 1864, L. osorio Machado, 2012, L. 637 tirajana Machado, 2012, and L. sp. aff. tirajana. Tenerife (4 species) L. tessellatus (Brulle, 1839), L. 638 freyi Uyttenboogaart, 1940, L. punctiger Machado, 2016, and L. canescens Machado, 2016. La Palma (1 species): L. auarita Machado, 2016. El Hierro (1 species): L. bimbache Machado, 2011. Sampling sites are colour coded to be consistent with island colour coding in Figure 5 and Figure S1. Geographic coordinates of sampling sites, and the taxonomic species assignment of samples from each location are provided in Table S2.2 in Appendix 2. Also shown is a polygon describing 643 the minimum geographic range of mtDNA haplotypes and their descendants from Tenerife that 644 645 646 647 Figure 5. Haplotype network. A resolved haplotype network representing the relationships among 648 649 195 mtDNA haplotypes obtained from 633 bp of mtDNA sequence data for the COll gene for 396 650 individuals of the Laparocerus tessellatus complex. Haplotypes are colour coded with respect to island: yellow - Gran Canaria, blue - Tenerife, green - La Palma, pink - El Hierro. Haplotypes from are ancestral to La Palma haplotypes (see text). Sampling sites from Faria et al. (2016) are indicated with a white dot inside the coloured circle. Tenerife that are ancestral to La Palma, or closely related to haplotypes that are ancestral to La Palma (referred to as TF-LP haplotypes in the text), are shown in light blue. Extinct or unsampled haplotypes are shown as small black filled circles. The grey arrow indicates the most recent common ancestral haplotype of the complex, determined by rooting with the closely related species L. vicinus Lindberg, 1953. Coloured pointed rectangles represent sets of potential ancestral haplotypes, from which at least one haplotype colonised a new island, with colonisation direction indicated by a colour gradient and pointed end to the rectangle (see Figure 3). 


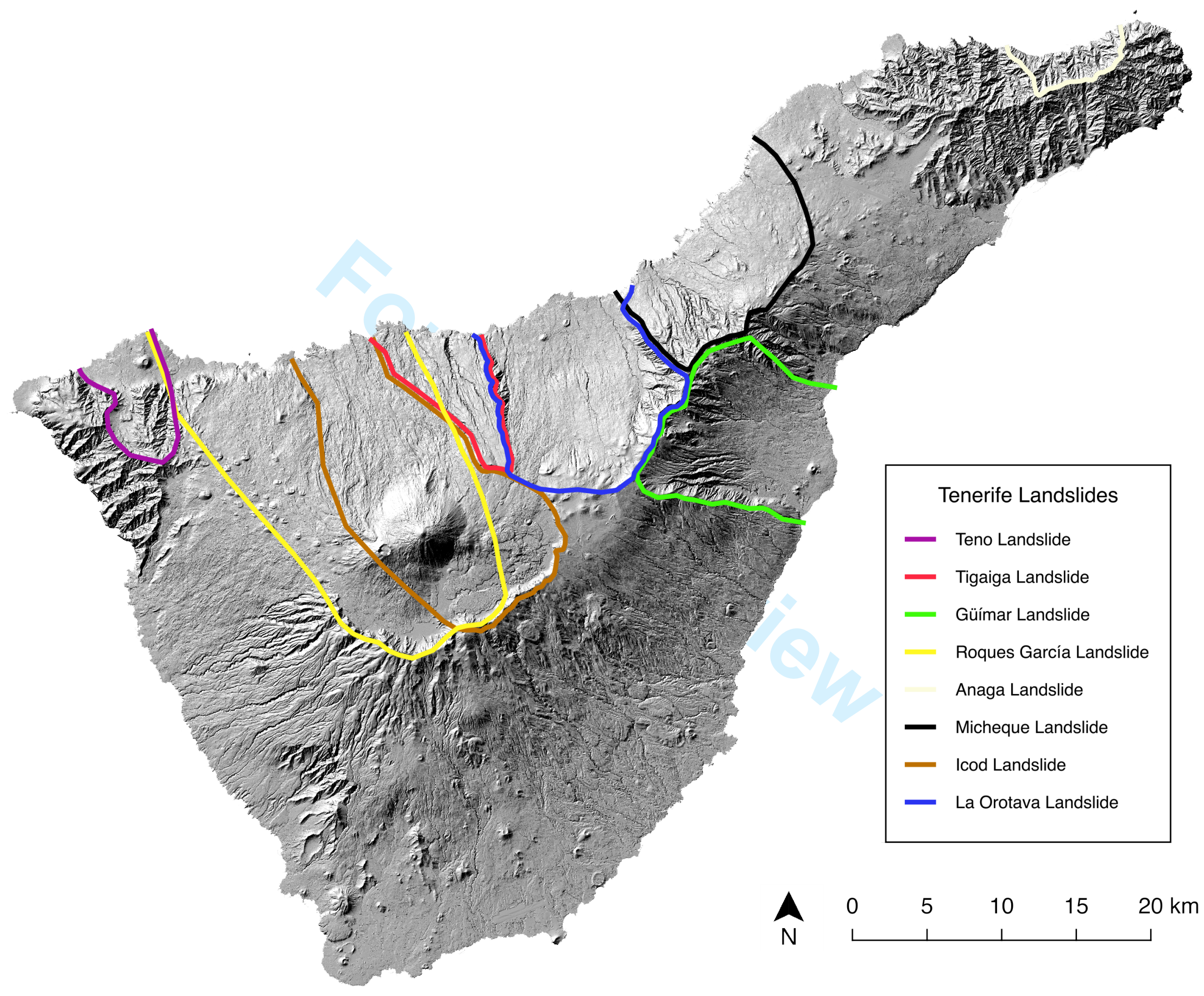




\section{Page 29 of 42}

Journal of Biogeography

1
2
3
4
5
6
7
8
9
10
11
12
13
14
15
16
17
18
19
20
21
22
23
24
25
26
27
28
29
30
31
32
33
34
35
36
37
38
39
40
41



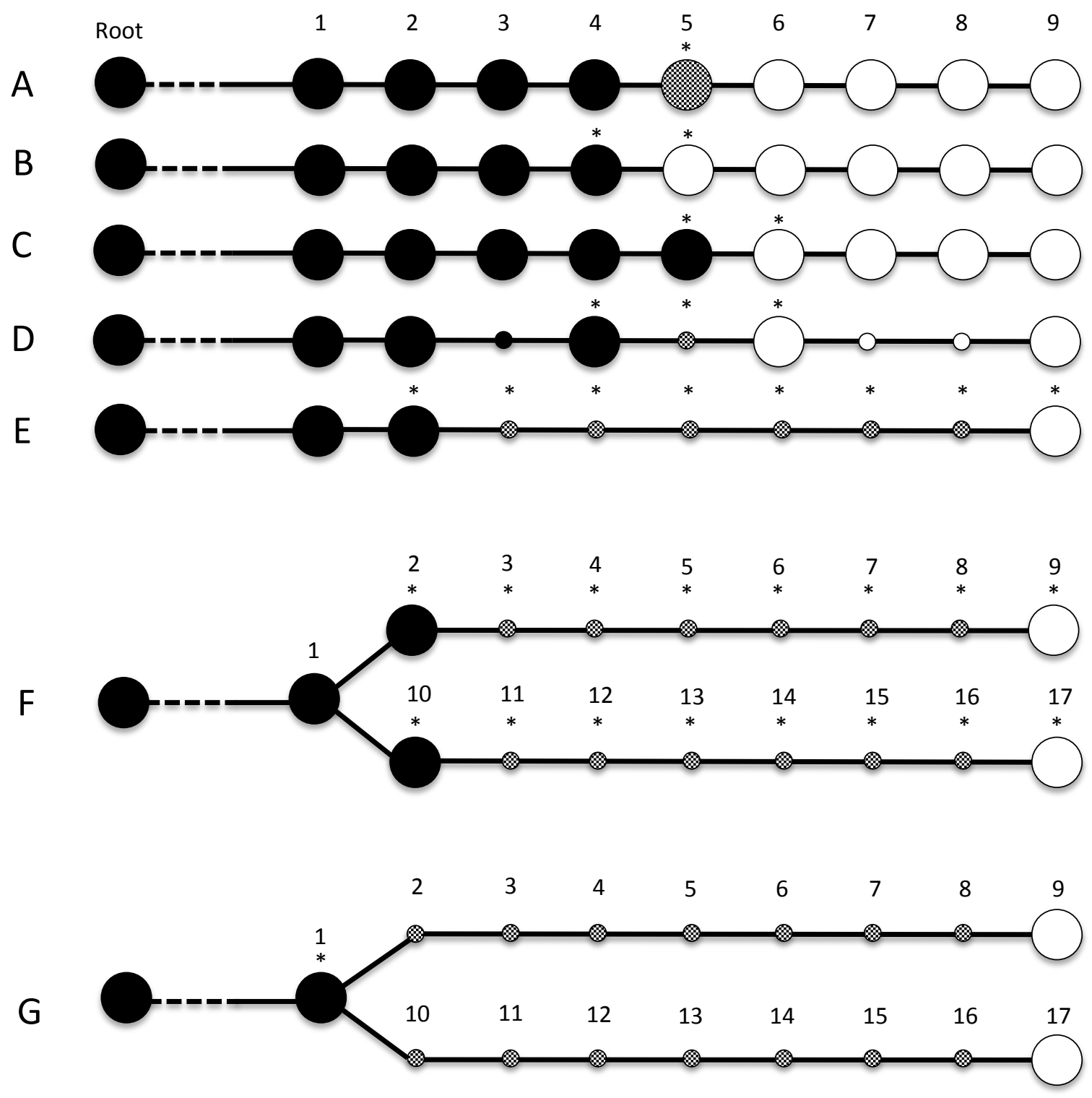


\section{Page 31 of 42}

Journal of Biogeography
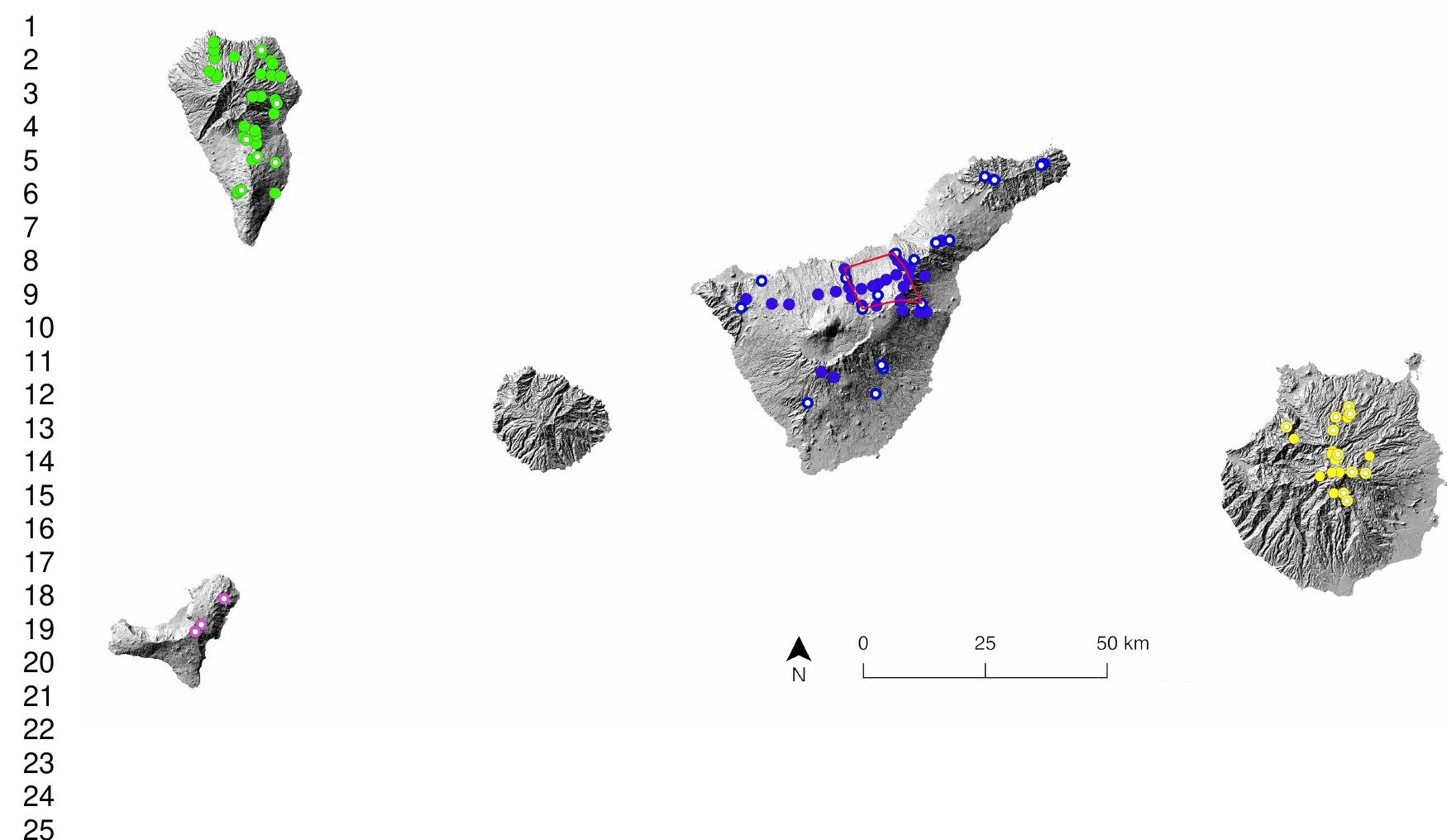


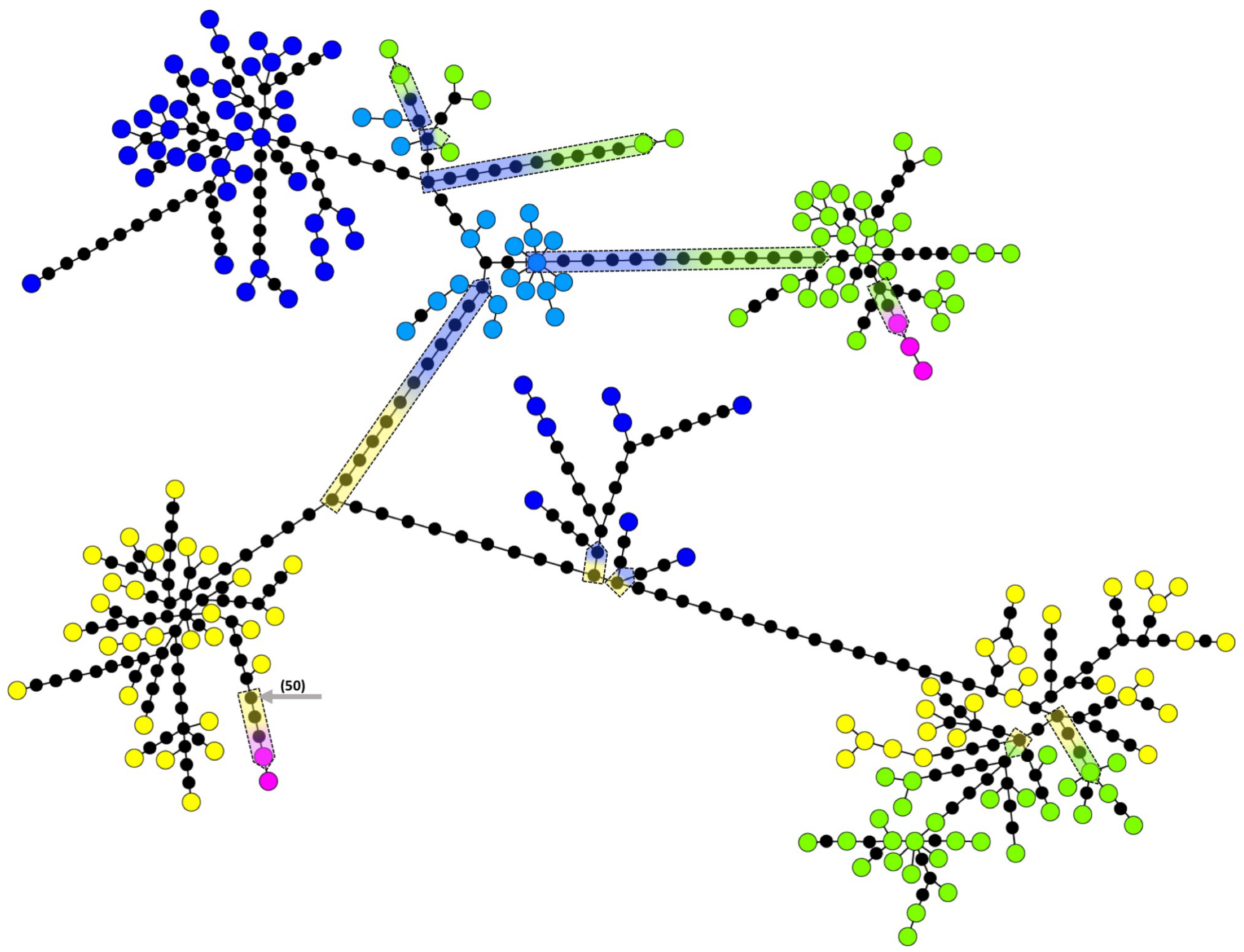




\section{Journal of Biogeography}

\section{SUPPORTING INFORMATION}

Evidence for mega-landslides as drivers of island colonisation

Víctor García-Olivares, Heriberto López, Jairo Patiño, Nadir Alvarez, Antonio Machado, Juan Carlos Carrecedo, Vicente Soler and Brent C. Emerson

Appendix S1. Details of documented landslides on the island of Tenerife

Table S1.1 Summary of documented landslides on the island of Tenerife, with marine deposit data when known. The area of each major plant community affected was calculated for those landslides where the limits of the surface area affected are clearly described by geomorphological evidence, such as landslide scars on island flanks. GIS shapes for the limits of the affected landslide areas were created based on previous published approximations, and on scars visualized on maps within the Canary Island cartography website (http://visor.grafcan.es/visorweb/). GIS shapes were then imported into maps of potential vegetation, and areas of each plant community were estimated using proprietary tools within the grafcan website.

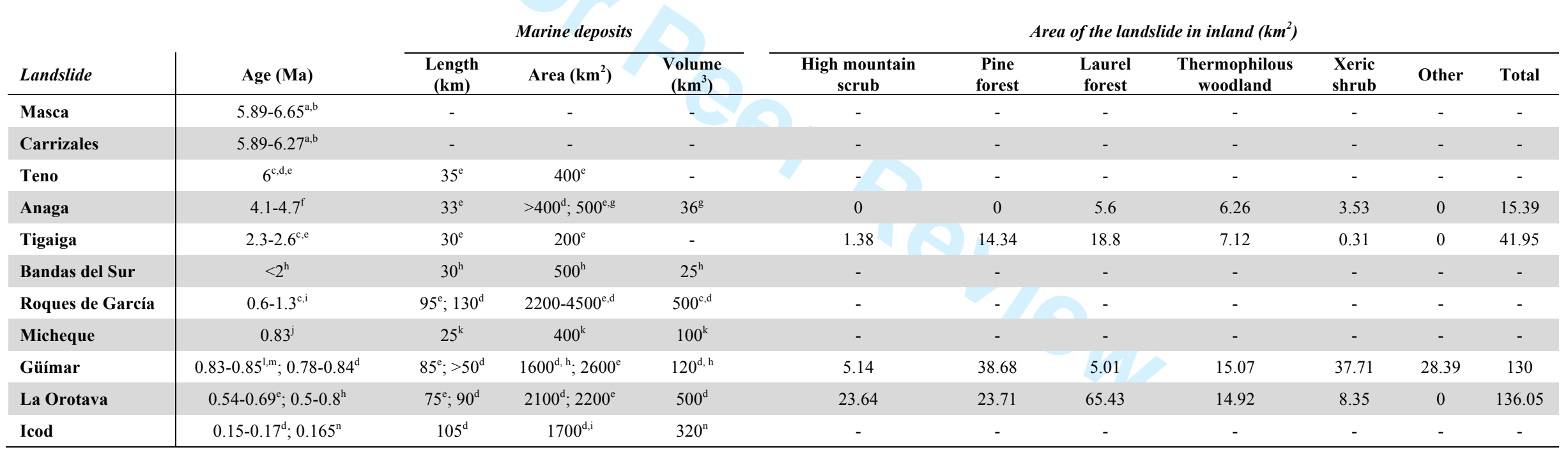

a: Longpré et al. (2009); b: Walter and Schmincke (2002); c: Cantagrel et al. (1999); d: Masson et al. (2002); e: Acosta et al. (2003); f: Walter et al. (2005); g: Llanes et al. (2003); h: Krastel et al. (2001); i: Watts and Masson (1998); j: Carracedo et al (2011); k: Ablay and Hürlimann (2000); 1: Hunt et al. (2013); m: Giachetti et al. (2011); n: Wynn et al. (2002).

Ablay, G., and M. Hürlimann. (2000). Evolution of the north flank of Tenerife by recurrent giant landslides. Journal of Volcanology and Geothermal Research, 103:135159.

Acosta, J., E. Uchupi, A. Muñoz, P. Herranz, C. Palomo, M. Ballesteros, and ZEE Working Group. (2003). Geologic evolution of the Canary Islands of Lanzarote, Fuerteventura, Gran Canaria and La Gomera and comparison of the landslides at these islands with those at Tenerife, La Palma and El Hierro. Mar. Geophys. Res., 24:1-40. 
Cantagrel, J. M., N. O. Arnaud, E. Ancochea, J. M. Fuster, and M. J. Huertas. (1999). Repeated debris avalanches on Tenerife and genesis of Las Cañadas caldera wall (Canary Islands). Geology, 27:739-742.

Carracedo, J. C. H. Guillou, S. Nomade, E. Rodríguez-Badiola, F. J. Pérez-Torrado, A. Rodríguez-González, R. Paris, V. R. Troll, S. Wiesmaier, A. Delcamp and J. L. Fernández-Turiel. (2011). Evolution of ocean-island rifts: The northeast rift zone of Tenerife, Canary Islands. Geological Society of America Bulletin. 123:562-584.

Giachetti, T., R. Paris, K. Kelfoun, and F. J. Perez-Torrado. (2011). Numerical modelling of the tsunami triggered by the Güímar debris avalanche, Tenerife (Canary Islands): Comparison with field-based data. Mar. Geol., 284:189-202.

Hunt, J. E., R. B. Wynn, P. J. Talling, and D. G. Masson. (2013). Turbidite record of frequency and source of large volume (>100 km3) Canary Island landslides in the last 1.5 Ma: Implications for landslide triggers and geohazards. Geochem. Geophys. Geosyst., 14:2100-2123.

Krastel, S., H.-U. Schmincke, C. L. Jacobs, R. Rihm, T. P. Le Bas, and B. Alibes. (2001). Submarine landslides around the Canary Islands, J. Geophys. Res., 106:39773997.

Llanes, P., A. Muñoz, A. Muñoz-Martın, J. Acosta, P. Herranz, A. Carbo, and C. Palom. (2003). Morphological and structural analysis in the Anaga offshore massif, Canary Islands: fractures and debris avalanches relationships. Mar. Geophys. Res., 24, 91-112

Longpré, M.-A., V. R. Troll, T. R. Walter, and T. H. Hansteen. (2009). Volcanic and geochemical evolution of the Teno massif, Tenerife, Canary Islands: Some repercussions of giant landslides on ocean island magmatism, Geochem. Geophys. Geosyst., 10:Q1201.

Masson, D. G., A. B. Watts, M. R. J. Gee, R. Urgeles, N. C. Mitchell, T. Le Bas, and M. Canals. (2002). Slope failures on the flanks of the Western Canary Islands. Earth Science Reviews 57:1-35.

Walter, T., and H.-U. Schmincke. (2002). Rifting, recurrent landsliding and Miocene structural reorganisation of NW-Tenerife (Canary Islands), Int. J. Earth Sci., 91:615628.

Walter, T. R., V. R. Troll, B. Cailleau, A. Belousov, H.-U. Schmincke, F. Amelung, and P. v.d. Bogaard. (2005). Rift zone reorganization through flank instability in ocean island volcanoes: an example from Tenerife, Canary Islands. Bull. Volcanol., 67:281-291.

Watts, A. B., and D. G. Masson. (1998). Reply to comment on: A giant land-slide on the northern flank of Tenerife, Canary Islands, by A. B. Watts and D. G. Masson. J. Geophys. Res., 103:9948-9951.

Wynn, R. B., P. P. E. Weaver, D. A. V. Stow, and D. G. Masson. (2002). Turbidite depositional architecture across three interconnected deepwater basins on the northwest African margin. Sedimentology, 49:1441-1462. 


\section{Journal of Biogeography \\ SUPPORTING INFORMATION}

Evidence for mega-landslides as drivers of island colonisation

Víctor García-Olivares, Heriberto López, Jairo Patiño, Nadir Alvarez, Antonio Machado, Juan Carlos Carrecedo, Vicente Soler and Brent C. Emerson

Appendix S2. Details of sampling locations and the taxonomic assignment of samples, and the Bayesian phylogenetic tree constructed from the 194 unique mtDNA haplotypes obtained from the sequences of 394 individuals. 


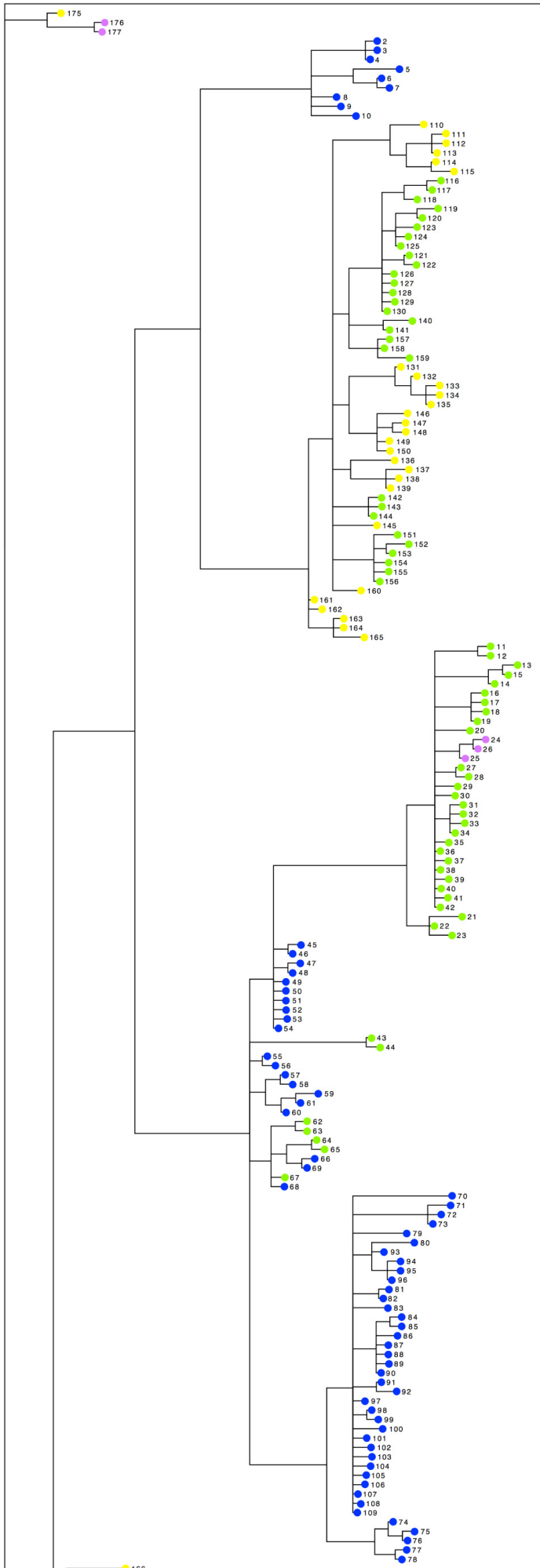

Figure S2.1. Bayesian phylogenetic tree constructed from 195 haplotypes for the mtDNA COII gene sampled from the Laparocerus tessellatus complex. Haplotype colour represents island of origin (see Fig. 3). See Supplemental Experimental Procedures for more details. 
Table S2.2. Details of sampling locations, the number of individuals sampled at each location, and their taxonomic assignment.

\begin{tabular}{|c|c|c|c|c|c|c|c|}
\hline Island & Locality & Locality Code & Lat. & Long. & $\begin{array}{l}\text { Taxonomic } \\
\text { assignment }\end{array}$ & $\begin{array}{c}\text { No. } \\
\text { Individuals }\end{array}$ & Source \\
\hline \begin{tabular}{|l|} 
Gran Canaria \\
\end{tabular} & Las Huertecillas & \begin{tabular}{|l|}
$\mathrm{C} 01$ \\
\end{tabular} & \begin{tabular}{|l|}
28.08554312 \\
\end{tabular} & -15.55989249 & L. obsitus & 2 & This study \\
\hline Gran Canaria & Las Huertecillas & $\mathrm{C} 01$ & 28.08554312 & -15.55989249 & L. osorio & 1 & Faria et al. 2015 \\
\hline Gran Canaria & Degollada de Osorio & $\mathrm{C} 02$ & 28.07254322 & -15.55794230 & L. sp. aff. tirajana & 5 & Faria et al. 2015 \\
\hline Gran Canaria & Laguna de Valleseco & $\mathrm{C} 03$ & 28.06506291 & -15.56382636 & L. obsitus & 2 & \begin{tabular}{|l|} 
This study \\
\end{tabular} \\
\hline Gran Canaria & \begin{tabular}{|l|} 
Barranco Oscuro \\
\end{tabular} & $\mathrm{C} 04$ & 28.06775026 & -15.58813215 & L. obsitus & 4 & Faria et al. 2015; this study \\
\hline \begin{tabular}{|l|} 
Gran Canaria \\
\end{tabular} & Barranco Oscuro & $\mathrm{C} 04$ & 28.06775026 & -15.58813215 & L. osorio & 6 & Faria et al. 2015; this study \\
\hline Gran Canaria & Barranco los Cazadores & $\mathrm{C} 05$ & 28.04327617 & -15.59488702 & L. obsitus & 2 & This study \\
\hline Gran Canaria & \begin{tabular}{|l|} 
Barranco los Cazadores \\
\end{tabular} & $\mathrm{C} 05$ & 28.04327617 & -15.59488702 & L. osorio & 3 & Faria et al. 2015 \\
\hline \begin{tabular}{|l|} 
Gran Canaria \\
\end{tabular} & Casa Forestal de Tamadaba & $\mathrm{C} 06$ & 28.05323863 & -15.69192219 & L. microphthalmus & 9 & Faria et al. 2015; this study \\
\hline Gran Canaria & Pico del Majadal & $\mathrm{C} 07$ & 28.03067996 & -15.67753554 & L. microphthalmus & 2 & This study \\
\hline Gran Canaria & Cruz de Tejeda & $\mathrm{C} 08$ & 28.00513303 & -15.59791167 & L. microphthalmus & 3 & This study \\
\hline Gran Canaria & Infra Cruz de Tejeda & $\mathrm{C} 09$ & 27.99958826 & -15.60048465 & L. obsitus & 2 & This study \\
\hline Gran Canaria & Barranco de la Mina & $\mathrm{C} 10$ & 27.99852595 & -15.58727789 & L. obsitus & 2 & Faria et al. 2015 \\
\hline Gran Canaria & Barranco de la Mina & $\mathrm{C} 10$ & 27.99852595 & -15.58727789 & L. osorio & 3 & \begin{tabular}{|l|} 
This study \\
\end{tabular} \\
\hline Gran Canaria & \begin{tabular}{|l|} 
Las Casillas \\
\end{tabular} & $\mathrm{C} 11$ & 27.99277738 & -15.52195750 & L. obsitus & 2 & This study \\
\hline Gran Canaria & Degollada de Becerra & $\mathrm{C} 12$ & 27.98854334 & -15.59328465 & L. obsitus & 2 & This study \\
\hline Gran Canaria & Barranco de los Cernícalos & $\mathrm{C} 13$ & 27.96126336 & -15.53148454 & L. sp. aff. tirajana & 5 & Faria et al. 2015; this study \\
\hline Gran Canaria & Cumbre. Pico Redondo & $\mathrm{C} 14$ & \begin{tabular}{|l|}
27.96466481 \\
\end{tabular} & -15.55926738 & L. sp. aff. tirajana & 5 & Faria et al. 2015; this study \\
\hline Gran Canaria & Llanos de la Pez & $\mathrm{C} 15$ & 27.96539529 & -15.58548187 & L. obsitus & 2 & This study \\
\hline \begin{tabular}{|l|} 
Gran Canaria \\
\end{tabular} & Supra Ayacata & $\mathrm{C} 16$ & 27.96511834 & -15.60155445 & L. tirajana & 2 & This study \\
\hline Gran Canaria & Lomo Aserrador & $\begin{array}{c}\mathrm{C} 17 \\
\end{array}$ & 27.95949872 & -15.62689883 & L. tirajana & 4 & This study \\
\hline Gran Canaria & Casa forestal Pilancones & $\mathrm{C} 18$ & 27.92719590 & -15.59940314 & L. tirajana & 1 & This study \\
\hline Gran Canaria & \begin{tabular}{|l|} 
Barranco Tirajana \\
\end{tabular} & $\mathrm{C} 19$ & 27.92605460 & -15.57921238 & L.tirajana & 3 & Faria et al. 2015; this study \\
\hline \begin{tabular}{|l|} 
Gran Canaria \\
\end{tabular} & San Bartolome de Tirajana & $\mathrm{C} 20$ & 27.91562810 & -15.57493941 & L. tirajana & 2 & This study \\
\hline Gran Canaria & San Bartolomé, Km 1 & $\mathrm{C} 21$ & 27.91213562 & -15.57252269 & L. tirajana & 12 & Faria et al. 2015 \\
\hline El Hierro & Monte Ajares, $600 \mathrm{~m}$ & $\mathrm{H} 02$ & 27.80306251 & -17.91735339 & L. bimbache & 2 & Faria et al. 2015 \\
\hline El Hierro & Piedras Blancas, San Andrés & $\mathrm{H} 06$ & 27.75615779 & -17.96588963 & L. bimbache & 2 & Faria et al. 2015 \\
\hline El Hierro & Infra Montaña Masilva & $\mathrm{H} 08$ & 27.74329951 & -17.97906625 & L. bimbache & 2 & Faria et al. 2015 \\
\hline La Palma & Ermita Santa Cecilia & $\mathrm{P} 01$ & 28.55312588 & -17.86759048 & L. auarita & 2 & \begin{tabular}{|l|} 
This study \\
\end{tabular} \\
\hline La Palma & Don Mendo Inferior & $\mathrm{P} 02$ & 28.55635515 & -17.86673813 & L. auarita & 1 & This study \\
\hline La Palma & Don Mendo Superior & $\mathrm{P} 03$ & 28.55918404 & -17.85878435 & L. auarita & 5 & Faria et al. 2015; this study \\
\hline La Palma & Caldereta de Mazo & $\mathrm{P} 04$ & 28.55171613 & -17.78852885 & L. auarita & 4 & This study \\
\hline La Palma & Montaña de Venijobre & $\mathrm{P} 05$ & 28.60832065 & -17.78591420 & L. auarita & 12 & Faria et al. 2015; this study \\
\hline La Palma & Refugio del Pilar & $\mathrm{P} 06$ & 28.61465974 & -17.83430130 & L. auarita & 2 & This study \\
\hline La Palma & Pared Vieja & P07 & 28.61991369 & -17.82330969 & L. auarita & 5 & Faria et al. 2015; this study \\
\hline La Palma & Fuente Guairín $1400 \mathrm{~m}$ & $\mathrm{P} 08$ & \begin{tabular}{|l|}
28.64466749 \\
\end{tabular} & -17.82496467 & L. auarita & 5 & This study \\
\hline La Palma & Supra El Paso, $870 \mathrm{~m}$. & P09 & 28.65230896 & -17.84558086 & L. auarita & 7 & Faria et al. 2015 \\
\hline La Palma & Supra El Paso, $837 \mathrm{~m}$ & P10 & 28.65633803 & -17.85215283 & L. auarita & 2 & \begin{tabular}{|l|} 
This study \\
\end{tabular} \\
\hline La Palma & Cumbre Nueva, $1400 \mathrm{~m}$ & P11 & 28.66020837 & -17.82546337 & L. auarita & 5 & This study \\
\hline La Palma & Pista de la Cumbre Nueva km 6 & P12 & 28.66844581 & -17.82710614 & L. auarita & 5 & This study \\
\hline La Palma & Pista de Ferrer Inferior & $\mathrm{P} 13$ & 28.67692853 & -17.84972415 & L. auarita & 2 & This study \\
\hline La Palma & Barranco de la Madera & P14 & 28.69902060 & -17.78647300 & L. auarita & 2 & \begin{tabular}{|l|} 
This study \\
\end{tabular} \\
\hline La Palma & Montaña Tagoja B & P15 & 28.71770148 & -17.77949856 & L. auarita & 3 & Faria et al. 2015 \\
\hline La Palma & Montaña Tagoja A & P16 & 28.72455336 & -17.78274993 & L. auarita & 5 & \begin{tabular}{|l|} 
This study \\
\end{tabular} \\
\hline La Palma & Fuente de Olén & P17 & 28.73150875 & -17.81321665 & L. auarita & 5 & This study \\
\hline La Palma & Picos de las Nieves & P18 & 28.73144181 & -17.83024401 & L. auarita & 2 & This study \\
\hline La Palma & Las Moradas 2000 & P19 & 28.76854840 & -17.90470811 & L. auarita & 3 & This study \\
\hline La Palma & Pinar de la Garafía $1900 \mathrm{~m}$ & $\mathrm{P} 20$ & 28.77295172 & -17.90463565 & L. auarita & 2 & This study \\
\hline La Palma & Pinar de la Garafía $1450 \mathrm{~m}$ & P21 & 28.78029274 & -17.91932624 & L. auarita & 2 & This study \\
\hline La Palma & Cueva de la Zarza & P22 & 28.80500749 & -17.90804415 & L. auarita & 6 & This study \\
\hline La Palma & Montaña de las Varas & $\mathrm{P} 23$ & 28.81950108 & -17.90894892 & L. auarita & 5 & This study \\
\hline La Palma & Juan Adalid, $600 \mathrm{~m}$ & P24 & 28.83406532 & -17.90866785 & L. auarita & 1 & This study \\
\hline La Palma & Barranco de las Traviesas, $924 \mathrm{~m}$ & $\mathrm{P} 25$ & 28.80646150 & -17.86624023 & L. auarita & 5 & \begin{tabular}{|l|} 
This study \\
\end{tabular} \\
\hline La Palma & Llanada de Barlovento & $\mathrm{P} 26$ & 28.81725810 & -17.80925143 & L. auarita & 5 & Faria et al. 2015 \\
\hline La Palma & Laguna de Barlovento & P27 & 28.81173517 & -17.80936941 & L. auarita & 5 & \begin{tabular}{|l|} 
This study \\
\end{tabular} \\
\hline La Palma & \begin{tabular}{|l|} 
Los Tilos \\
\end{tabular} & $\mathrm{P} 28$ & 28.79697693 & -17.78941412 & L. auarita & 5 & This study \\
\hline La Palma & Las Lomadas & P29 & 28.79118302 & -17.78605468 & L. auarita & 5 & This study \\
\hline La Palma & Marcos y Cordero & P30 & 28.77274777 & -17.81202970 & L. auarita & 5 & This study \\
\hline
\end{tabular}




\begin{tabular}{|c|c|c|c|c|c|c|c|}
\hline La Palma & Infra Marcos y Cordero & P31 & 28.76956776 & -17.78921668 & L. auarita & 5 & This study \\
\hline La Palma & Cubo de la Galga & P32 & 28.76701695 & -17.76984079 & L. auarita & 5 & This study \\
\hline Tenerife & Chinobre A & T04 & 28.55855948 & -16.17519235 & L. tessellatus & 1 & Faria et al. 2015 \\
\hline Tenerife & El Pijaral A & T05 & 28.55558324 & -16.18118025 & L. tessellatus & 12 & Faria et al. 2015 \\
\hline Tenerife & Cruz del Carmen & $\mathrm{T} 08$ & 28.53192475 & -16.28007026 & L. tessellatus & 2 & Faria et al. 2015 \\
\hline Tenerife & Pista Las Yedras & $\mathrm{T} 10$ & 28.53869269 & -16.30013310 & L. tessellatus & 1 & Faria et al. 2015 \\
\hline Tenerife & Los Morros (Altos Vilaflor) & $\mathrm{T} 100$ & 28.17835785 & -16.63134339 & L. canescens & 1 & This study \\
\hline Tenerife & Granadilla (Las Vegas) & $\mathrm{T} 105$ & 28.14503420 & -16.54520667 & L. canescens & 6 & Faria et al. 2015 \\
\hline Tenerife & El Contador & $\mathrm{T} 112$ & 28.19143403 & -16.52742558 & L. canescens & 2 & Faria et al. 2015 \\
\hline Tenerife & Cumbres de Arico & $\mathrm{T} 113$ & 28.19770104 & -16.53115154 & L. canescens & 3 & Faria et al. 2015 \\
\hline Tenerife & Lomo del Retamar & $\mathrm{T} 122$ & 28.29691862 & -16.48256482 & L. canescens & 4 & This study \\
\hline Tenerife & Montaña Las Raíces & $\mathrm{T} 123$ & 28.29323746 & -16.44797825 & L. punctiger & 2 & This study \\
\hline Tenerife & Montaña de Anocheza A & $\mathrm{T} 124$ & 28.29324808 & -16.43328514 & L. punctiger & 5 & This study \\
\hline Tenerife & Las Raíces & T20 & 28.42382434 & -16.37923736 & L. punctiger & 11 & Faria et al. 2015 \\
\hline Tenerife & Montaña Pico las Flores & $\mathrm{T} 21$ & 28.42380586 & -16.39610270 & L. punctiger & 1 & This study \\
\hline Tenerife & Fuente Fría. Tacoronte & $\mathrm{T} 22$ & 28.42011452 & -16.40749833 & L. tessellatus & 1 & Faria et al. 2015 \\
\hline Tenerife & Barranco de Bensa & $\mathrm{T} 41$ & 28.39007943 & -16.45466060 & L.tessellatus & 3 & Faria et al. 2015 \\
\hline Tenerife & Gorgo & $\mathrm{T} 43$ & 28.35900553 & -16.43337186 & L. tessellatus & 1 & This study \\
\hline Tenerife & Mirador de Chipeque & $\mathrm{T} 46$ & 28.37382697 & -16.46375524 & L. tessellatus & 5 & This study \\
\hline Tenerife & Choza Almadi & T50 & 28.38142911 & -16.47936090 & L. tessellatus & 4 & This study \\
\hline Tenerife & Las Lajitas & T51 & 28.39031952 & -16.48924102 & L. tessellatus & 7 & This study \\
\hline Tenerife & Supra La Corujera & T53 & 28.40303863 & -16.49228702 & L. tessellatus & 5 & Faria et al. 2015; this study \\
\hline Tenerife & El Nogalito & $\mathrm{T} 54$ & 28.40120553 & -16.49567039 & L. tessellatus & 5 & This study \\
\hline Tenerife & Montaña de Ayosa & $\mathrm{T} 55$ & 28.35769475 & -16.46666606 & L. tessellatus & 5 & This study \\
\hline Tenerife & Peña Rajada & $\mathrm{T} 56$ & 28.36350078 & -16.49300887 & L. tessellatus & 5 & This study \\
\hline Tenerife & Corral de los Lucas & T57 & 28.34126307 & -16.47890596 & L. punctiger & 5 & This study \\
\hline Tenerife & Barranco del Agua. Güimar & T59 & 28.30806238 & -16.44235595 & L. punctiger & 9 & Faria et al. 2015 \\
\hline Tenerife & Lomo los Pajales & $\mathrm{T} 60$ & 28.31639226 & -16.48613925 & L. punctiger & 5 & This study \\
\hline Tenerife & Lomo Chillero & T61 & 28.35539266 & -16.51460597 & L. tessellatus & 5 & This study \\
\hline Tenerife & Morro Quemado & $\mathrm{T} 62$ & 28.34795435 & -16.53172067 & L. tessellatus & 5 & This study \\
\hline Tenerife & Las Jaritas & T63 & 28.34422815 & -16.54282729 & L. tessellatus & 2 & This study \\
\hline Tenerife & Montaña Bermeja & T64 & 28.32716206 & -16.53319714 & L. freyi & 2 & Faria et al. 2015 \\
\hline Tenerife & Roque Caramujo & $\mathrm{T} 65$ & 28.30758082 & -16.53692392 & L. freyi & 5 & This study \\
\hline Tenerife & Los Amontaderos & T66 & 28.34006167 & -16.56709584 & cf. L. freyi & 5 & This study \\
\hline Tenerife & El Portillo & T67 & 28.30291210 & -16.56654085 & L. freyi & 3 & Faria et al. 2015 \\
\hline Tenerife & Infra El Portillo & T68 & 28.30911349 & -16.56722319 & L. freyi & 2 & This study \\
\hline Tenerife & Vista la Chapa & T69 & 28.32568840 & -16.58786491 & L. freyi & 3 & This study \\
\hline Tenerife & Cruz de Joaquín & $\mathrm{T} 70$ & 28.34281845 & -16.59322010 & L. freyi & 5 & This study \\
\hline Tenerife & Icod el Alto & $\mathrm{T} 71$ & 28.36095843 & -16.59862289 & L. freyi & 4 & Faria et al. 2015 \\
\hline Tenerife & La Corona & $\mathrm{T} 72$ & 28.37783472 & -16.60094739 & cf L. tessellatus & 2 & This study \\
\hline Tenerife & Lomo Blanco & $\mathrm{T} 73$ & 28.33658388 & -16.62065758 & L. freyi & 2 & This study \\
\hline Tenerife & Hoya Benjaminas & $\mathrm{T} 74$ & 28.33271255 & -16.65817491 & L. tessellatus & 2 & This study \\
\hline Tenerife & Llano de los Cuervos & $\mathrm{T} 75$ & 28.31620449 & -16.71956612 & L. tessellatus & 2 & This study \\
\hline Tenerife & Tanque Bajo & $\mathrm{T} 76$ & 28.36146458 & -16.77505070 & L. tessellatus & 1 & Faria et al. 2015 \\
\hline Tenerife & Arenas Negras & $\mathrm{T} 77$ & 28.31853497 & -16.75554195 & L. tessellatus & 1 & This study \\
\hline Tenerife & El Lomito & T79 & 28.32895645 & -16.80887055 & L. tessellatus & 2 & This study \\
\hline Tenerife & Cumbre de Bolico & $\mathrm{T} 80$ & 28.31338338 & -16.82018098 & L. tessellatus & 2 & Faria et al. 2015 \\
\hline Tenerife & Ifonche & T94 & 28.13267228 & -16.68803953 & L. punctiger & 2 & Faria et al. 2015 \\
\hline Tenerife & Fuente Fría. Altos Vilaflor & T96 & 28.18892538 & -16.65694869 & L. canescens & 1 & This study \\
\hline
\end{tabular}




\section{Journal of Biogeography}

\section{SUPPORTING INFORMATION}

Evidence for mega-landslides as drivers of island colonisation

Víctor García-Olivares, Heriberto López, Jairo Patiño, Nadir Alvarez, Antonio Machado, Juan

Carlos Carrecedo, Vicente Soler and Brent C. Emerson

Appendix S3. Altitudinal sampling data for the Laparocerus tessellatus complex in Tenerife, and photographic evidence of floating vegetation resulting from the 1980 eruption of Mount St. Helens.

Table S3.3. Summary of the number of localities known in Tenerife for the tessellatus complex and the other species of Laparocerus, in altitudinal intervals of 100 macsl. Locality data from a collection of Laparocerus maintained by one of us (AMC) was used to estimate the altitudinal range of the Laparocerus tessellatus complex in Tenerife. Six hundred and forty-two sampling localities, encompassing all ecosystems in an altitudinal gradient from sea level to the highest altitudes of the island, were sampled for Laparocerus. Data are summarised within altitudinal intervals of 100 macsl in Table S3.3. Two hundred and forty-four localities included samples from the L. tessellatus complex, while the remaining 398 were sampled only for other species from the genus. Of the 83 localities sampled for Laparocerus at altitudes $\leq 300$ macsl, the L. tessellatus complex was sampled at only 4 , meaning that more than $98 \%$ of occurrence records for $L$. tessellatus are $>300$ macsl. The L. tessellatus complex is typical of altitudes above 764 macsl and below 1424 macsl (first and third quartiles of species distribution records), with a median and mean altitude of $1102 \mathrm{~m}$ and $1000 \mathrm{~m}$ respectively.

\begin{tabular}{|c|c|c|c|}
\hline $\begin{array}{l}\text { Latitudinal } \\
\text { intervals }\end{array}$ & $\begin{array}{c}\text { Frequency } L . \\
\text { tessellatus }\end{array}$ & $\begin{array}{c}\text { Frequency other } \\
\text { species }\end{array}$ & Total \\
\hline $0-99$ & 0 & 35 & 35 \\
\hline 100-199 & 3 & 21 & 24 \\
\hline $200-299$ & 1 & 23 & 24 \\
\hline $300-399$ & 3 & 21 & 24 \\
\hline $400-499$ & 5 & 18 & 23 \\
\hline $500-599$ & 10 & 26 & 36 \\
\hline $600-699$ & 18 & 30 & 48 \\
\hline $700-799$ & 27 & 37 & 64 \\
\hline $800-899$ & 30 & 47 & 77 \\
\hline $900-999$ & 22 & 20 & 42 \\
\hline 1000-1099 & 22 & 30 & 52 \\
\hline $1100-1199$ & 15 & 10 & 25 \\
\hline $1200-1299$ & 18 & 11 & 29 \\
\hline $1300-1399$ & 5 & 4 & 9 \\
\hline $1400-1499$ & 11 & 8 & 19 \\
\hline $1500-1599$ & 4 & 5 & 9 \\
\hline $1600-1699$ & 16 & 12 & 28 \\
\hline $1700-1799$ & 9 & 4 & 13 \\
\hline 1800-1899 & 3 & 3 & 6 \\
\hline 1900-1999 & 7 & 1 & 8 \\
\hline 2000-2099 & 8 & 8 & 16 \\
\hline $2100-2199$ & 2 & 9 & 11 \\
\hline $2200-2299$ & 4 & 7 & 11 \\
\hline $2300-2399$ & 1 & 2 & 3 \\
\hline
\end{tabular}




\begin{tabular}{|c|c|c|c|}
$2400-2499$ & 0 & 0 & 0 \\
\hline $2500-2599$ & 0 & 2 & 2 \\
\hline $2600-2699$ & 0 & 2 & 2 \\
\hline $2700-2799$ & 0 & 0 & 0 \\
\hline $2800-2899$ & 0 & 0 & 0 \\
\hline $2900-2999$ & 0 & 0 & 0 \\
\hline $3000-3099$ & 0 & 2 & 2 \\
\hline$>3100$ & 0 & 0 & 0 \\
\hline Total & 244 & 398 & 642 \\
\hline
\end{tabular}


During the eruption of Mt. St. Helens in 1980, a mega-landslide resulted in the deposition of tens of thousands of trees into Spirit Lake, producing a giant log raft that persisted for many years. The following photos, taken between two and three decades after the eruption, demonstrate the high floatability and temporal persistence of plant material deposited into a water body from a mega-landslide.

Photo 1: Agglomeration of logs on Spirit Lake, 22 years after the eruption and landslide (Author: Xpda). Logs are indicated with a black arrow added by the authors.

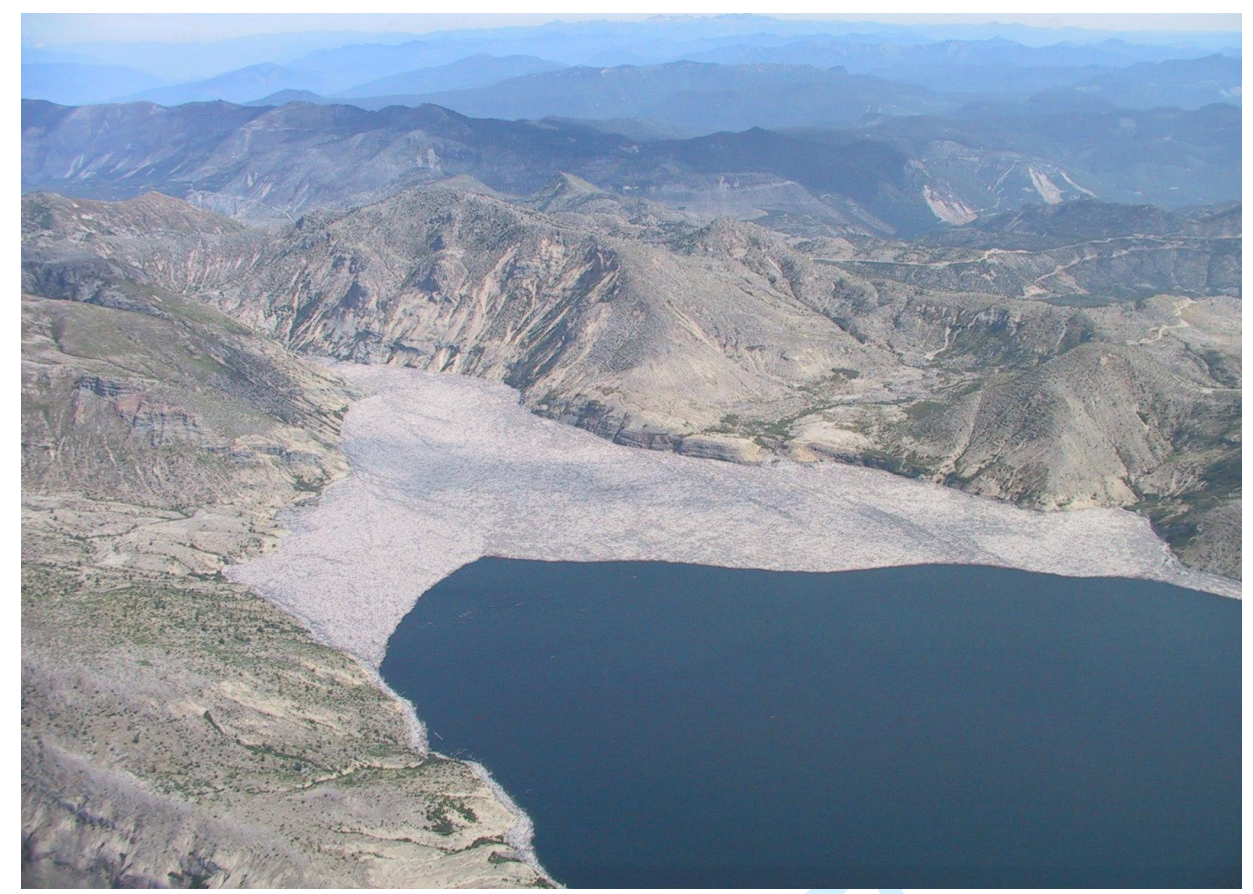

Photo 2. Trees drifting on Spirit Lake, with the open crater of Mount St. Helens open in the background, 32 years after the landslide and eruption (Author: Stephan Schulz)

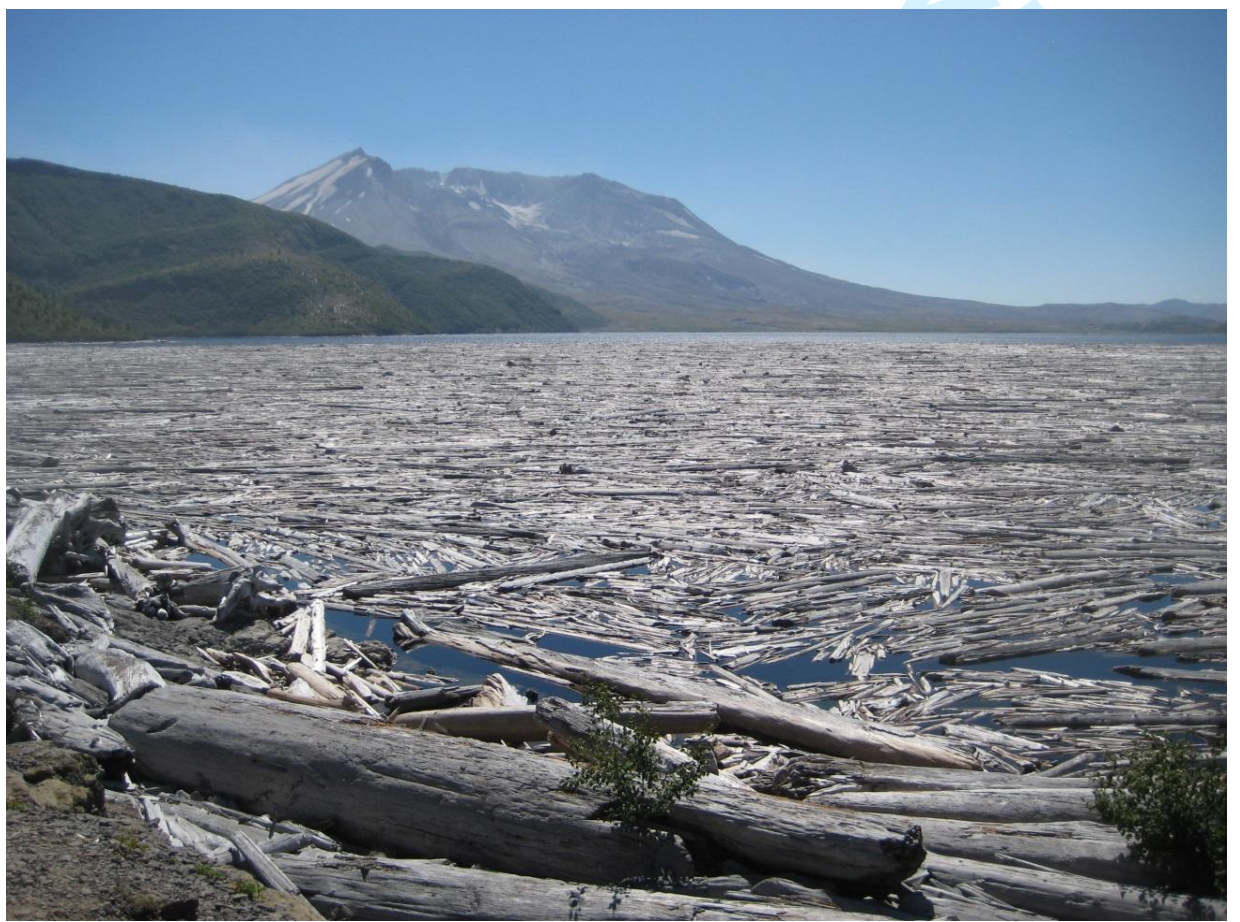


Photo 3. Hikers gazing at the logs covering Spirit Lake, near Mount St. Helens, 29 years after the eruption and landslide (Author: Etliebe).

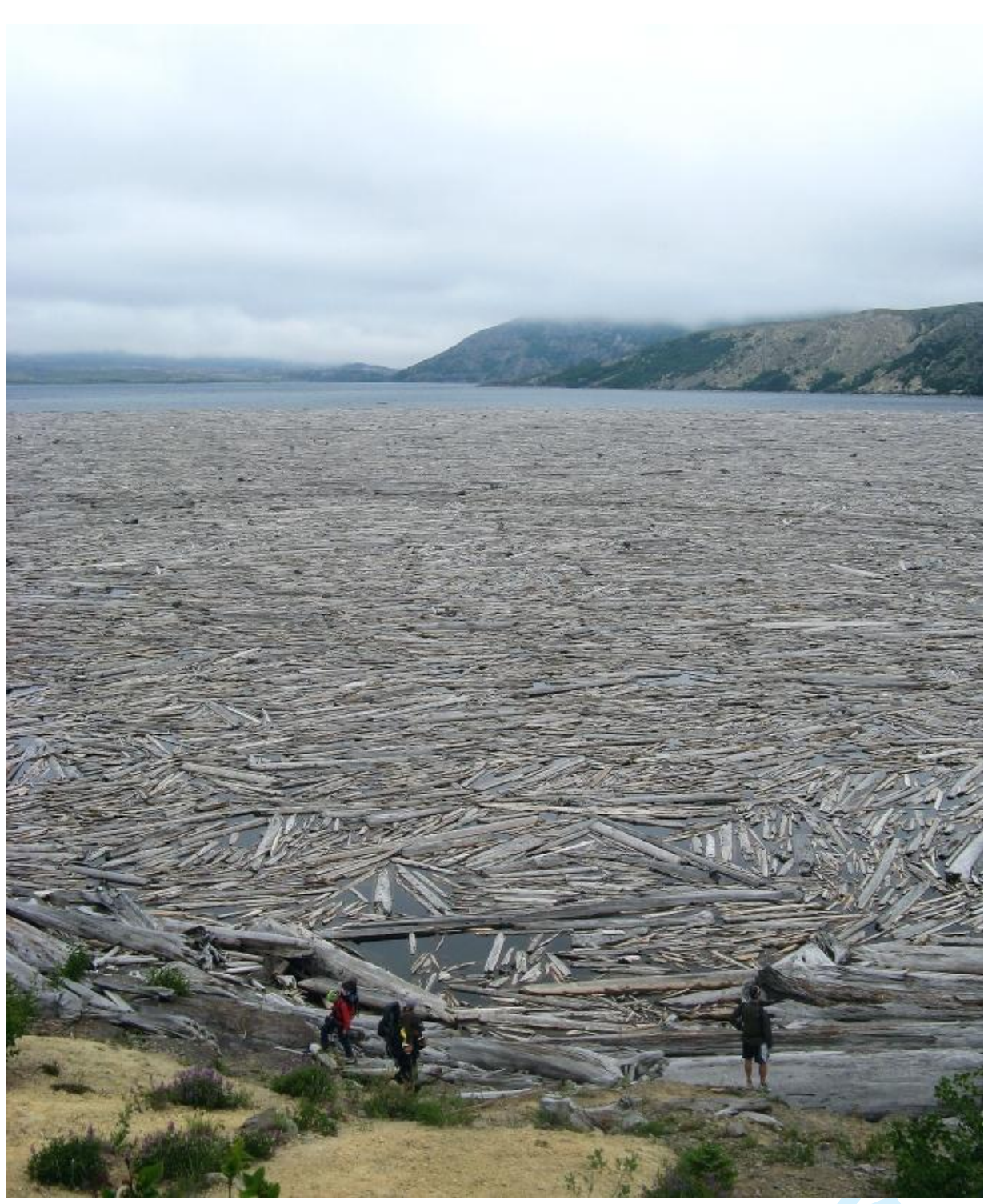

